\title{
Importance of biological parameters in assessing the status of Delphinus delphis
}

\author{
Sinéad Murphy ${ }^{1,2, *}$, Arliss Winship ${ }^{1}$, Willy Dabin ${ }^{3}$, Paul D. Jepson ${ }^{4}$, Rob Deaville ${ }^{4}$, \\ Robert J. Reid ${ }^{5}$, Chris Spurrier ${ }^{6}$, Emer Rogan ${ }^{2}$, Alfredo López ${ }^{7}$, Angel F. González ${ }^{8}$, \\ Fiona L. Read ${ }^{8}$, Marjan Addink ${ }^{9}$, Monica Silva ${ }^{10}{ }^{,}$Vincent Ridoux $^{2}$, \\ Jennifer A. Learmonth ${ }^{11}$, Graham J. Pierce ${ }^{11,12}$, Simon P. Northridge ${ }^{1}$ \\ ${ }^{1}$ Sea Mammal Research Unit, University of St Andrews, St Andrews KY16 8LB, UK \\ ${ }^{2}$ Department of Zoology, Ecology and Plant Science, University College Cork, Cork, Ireland \\ ${ }^{3}$ Centre de Recherche sur les Mammifères Marins, Institut du Littoral et de l'Environnement, Université de La Rochelle, \\ 17071 La Rochelle, France \\ ${ }^{4}$ Institute of Zoology, Regents Park, London NW1 4RY, UK \\ ${ }^{5}$ Wildlife Unit, SAC Veterinary Services, Inverness IV2 4JZ, UK \\ ${ }^{6}$ Natural History Museum, Cromwell Road, London SW7 5BD, UK \\ ${ }^{7}$ CEMMA, Apdo. 15 - 36380 Gondomar, Pontevedra, Spain \\ ${ }^{8}$ CSIC, Instituto de Investigaciones Marinas, Eduardo Cabello 6, 36208 Vigo, Spain \\ ${ }^{9}$ National Museum of Natural History, Darwinweg 22300 RA, Leiden, The Netherlands \\ ${ }^{10}$ Centro do Instituto do Mar (IMAR) da Universidade dos Açores, Dept de Oceanografia e Pescas, 9901-862 Horta, Portugal \\ ${ }^{11}$ School of Biological Science, University of Aberdeen, Zoology Building, Tillydrone Avenue, Aberdeen AB242TZ, UK \\ ${ }^{12}$ Instituto Español de Oceanografía, Centro Oceanográfico de Vigo, PO Box 1552, 36200 Vigo, Spain
}

\begin{abstract}
Short-beaked common dolphins Delphinus delphis in the eastern North Atlantic (ENA) are subject to mortality due to entanglement in various types of fishing gear. However, for this region, there is no population-level information available on trends in abundance, (incidental) mortality rates or even the actual distributional range. Working under the assumption that only 1 population exists in ENA waters, the current study presents basic life history data and investigates whether biological information obtained from postmortem data is, in itself, useful for managing this population. Life history parameters were estimated by analysing postmortem data obtained over a 16 yr period by UK, Irish, French, Galician (northwest Spain) and Portuguese stranding and bycatch observer programmes. An annual pregnancy rate of $26 \%$, a calving interval of $3.79 \mathrm{yr}$, an average age attained at sexual maturity of $8.22 \mathrm{yr}$ and an average length at sexual maturity of $188 \mathrm{~cm}$ were determined. With respect to the findings based solely on mortality data, significance testing failed to detect differences that could be construed as evidence of the population exhibiting what might be density-dependent compensatory responses. The low annual pregnancy rate reported throughout the sampling period may suggest either that the level of anthropogenic mortality did not cause a substantial population level decline, or a prey base declining at approximately the same rate as the dolphin population. However, this approach alone does not facilitate an assessment of the current state of the D. delphis population in the ENA. Population abundance estimates, trends in abundance and knowledge of factors that affect the dynamics of the population, such as annual mortality rates in fisheries, temporal variations in prey abundance and effects of contaminants on reproductive activity, are required not only to set management objectives, but also to give context to cross-sectional life history information.
\end{abstract}

KEY WORDS: Common dolphin $\cdot$ Delphinus delphis $\cdot$ Life history $\cdot$ Density-dependent $\cdot$ Control group · Eastern North Atlantic 


\section{INTRODUCTION}

It is important to determine life history parameters in marine mammals in order to assess changes in the dynamics of exploited populations as a result of directed fisheries or incidental bycatch (Eberhardt \& Siniff 1977). This is particularly the case for populations for which there is a lack of baseline information on the original population size prior to anthropogenic pressures and subsequent temporal changes in population abundance as a result of adverse anthropogenic activities. For large populations of oceanic delphinid species, such as the short-beaked common dolphin Delphinus delphis, longterm behavioural studies cannot be undertaken to determine birth and calf mortality rates, female reproductive success and calving intervals. In these circumstances, mortality data are valuable for modelling the viability of endangered and threatened populations, as they can be used to estimate life history parameters and assess the effects of extrinsic factors on the dynamics of a population (Stolen \& Barlow 2003).

Cetacean populations are regulated through density-dependent changes in reproduction and survival, and it has been proposed that food resources are the main causative agent in the expression of density dependence (Fowler 1984, 1987, Lockyer 1990), resulting in an increase in population growth rates at low densities and a decrease in growth rates at high densities (Hohn et al. 2007, and references therein). Further, females are under selective pressure to produce more offspring at a reduced population level, as individuals that increase their contribution to the population following a reduction below carrying capacity $(\mathrm{K})$ also contribute most to the genetic composition of succeeding generations (Fowler 1981). Large mammals are expected to show most of their density-dependent changes at population levels quite close to $\mathrm{K}$ (Fowler 1981), and for marine mammals, most models predict that maximum net productivity will occur at population sizes between 50 and $85 \%$ of $\mathrm{K}$ (density-dependent changes in age-specific birth and death rates; Taylor \& DeMaster 1993).

In long-lived mammal species, indices such as juvenile survival, reproductive parameters (e.g. age at first reproduction and birth rates) and the mean body size (or size of body parts) are influenced by the population level/density and are most sensitive to cumulative effects of exposure to conditions over space and time (Fowler 1984, Lockyer 1990). Juvenile survival is considered to be the optimum parameter for detecting changes in population level, as it is most likely influenced by conditions during gestation, the female's condition prior to gestation and environmental influences during lactation. According to initial studies on marine mammals, the 3 parameters (biological indices) most often observed to change with population density are age at sexual maturity, birth rate and juvenile survival (Fowler 1984). As long-lived marine mammal species have a low intrinsic rate of increase and attain sexual maturity at an older age, they must maximise their adult survival in order to persist (Wade 2002). It has therefore been hypothesised that the mechanism for regulation of increasing populations would be as follows: density dependence first affects the rate of immature survival, followed by the age at sexual maturity, birth rate and finally the adult survival rate (Wade 2002). The age groups expected to exhibit the most variability in expression of reproductive rates are the younger sexually mature age classes (Fowler 1984). In small cetaceans, the proportion of sexually mature females is also likely to be a reliable index of changing population status, followed by the proportion of females simultaneously pregnant and lactating (Chivers \& DeMaster 1994).

Two species of common dolphin, the short-beaked common dolphin Delphinus delphis and the longbeaked common dolphin $D$. capensis, are currently recognised (Heyning \& Perrin 1994, Jefferson \& Van Waerebeek 2002), although in the eastern North Atlantic (ENA), only D. delphis has been reported (Murphy et al. 2006, Natoli et al. 2006). Using both skull and mtDNA samples from the western North Atlantic (WNA) and ENA, Westgate $(2005,2007)$ ascertained that the 2 regions are not panmictic and therefore constitute separate populations. Recent genetic (using mtDNA and microsatellites) and skull morphometric studies within the ENA have suggested that only 1 population exists, as low levels or a lack of differentiation were observed (Murphy et al. 2006, Natoli et al. 2006, Viricel 2006, Amaral et al. 2007, Mirimin et al. 2007). Although D. delphis have been reported along the mid-Atlantic ridge (Doksaeter et al. 2008), samples analysed in the above-mentioned studies were obtained from European continental shelf and slope waters ranging from Scotland to Portugal, and adjacent oceanic waters of the Bay of Biscay. Due to a lack of sampling of individuals farther offshore, the actual distributional range of the ENA population is currently unknown, although a separate population exists in the Mediterranean Sea (Natoli et al. 2008).

To date, there is a lack of general knowledge on the population level status of Delphinus delphis in the ENA. Within this region, incidental capture of D. delphis in fishing gear has been reported in a large number of different net types/fisheries such as tuna driftnets (Rogan \& Mackey 2007), bass pelagic trawls (Northridge et al. 2006), UK gillnets (Northridge et al. 2007), Irish gill nets (Tregenza et al. 1997), Portuguese gill, beach seine and trawl nets (Silva \& Sequeira 2003), and Spanish trawls, gillnets, long-lines and 
seine nets (López et al. 2002). However, population size prior to and temporal changes in population abundance as a result of anthropogenic removal have not been assessed. Therefore, we assessed the validity of using biological parameters, estimated from postmortem data, in describing changes in the dynamics of the short-beaked common dolphin population in the ENA by investigating evidence of density-dependent compensatory responses.

Here we present detailed descriptions of life history parameters for Delphinus delphis in the ENA. We estimated reproductive parameters using data collected over a 16 yr sampling period by European stranding and observer bycatch programmes, and various statistical methodologies. Stranding data might not provide a representative sample for estimating the annual pregnancy rate (APR) for a population, as it may be composed of a high proportion of dolphins suffering from severe infectious or non-infectious disease and/or older individuals with lower reproductive rates. For that reason, the APR for a control group of 'healthy' individuals was also calculated. In addition to estimating growth and reproductive parameters for $D$. delphis in the ENA, we compared our results to those published on other common dolphin populations. We investigated the ENA data for evidence of density compensatory responses by examining for variations in biological indices/reproductive parameters during the 16 yr sampling period. Finally, we considered the value of mortality data as a tool for management of marine mammal populations, and undertook power analysis to determine the sample sizes required for detecting statistically significant temporal and geographic variations in the APR.

\section{MATERIALS AND METHODS}

Specimen and data collection. During the 16 yr sampling period (1990 to 2006), data were collated from 958 stranded or bycaught female Delphinus delphis by UK, Irish, French, Galician (northwest Spain) and Portuguese stranding $(87 \%)$ and observer bycatch programmes $(13 \%)$. Dissections of carcasses and pathological investigations were undertaken according to a standard postmortem protocol (Kuiken \& Garcia Hartmann 1991, Law 1994). During postmortem examinations, ovaries with associated reproductive tracts were removed. Ovaries were initially examined, then carefully dissected from the reproductive tract and preserved in $10 \%$ neutral buffered formalin. Lactation was assessed by (1) externally pressing the area around the mammary slit and noting any fluids emitting from the nipples, and (2) internally by sectioning through the mammary glands and noting the presence of milk. Pregnancy was established by the presence of an embryo/foetus. If a foetus was present, it was weighed, sexed if possible, and measured. Total body length (TBL) was measured to the nearest $\mathrm{cm}$, and body weight to the nearest $\mathrm{kg}$. However, as a number of postmortem examinations were carried out on board fishing vessels or on beaches, not all information could be collected from each carcass, so sample sizes vary between parameters.

Age determination. Individuals were aged by counting growth layer groups (GLGs) in their dentine. Tooth preparation methods were adapted from the protocol described by Lockyer (1995) and outlined further by Rogan et al. (2004). Cross-reading workshops were carried out between all laboratories involved in age determination. Based on a calibration study by Gurevich et al. (1980), 1 GLG in common dolphins is considered to represent $1 \mathrm{yr}$ of life. Each GLG is composed of 1 broad opaque layer followed by a narrow translucent layer. Ages were recorded to the nearest 0.5 GLG (6 mo).

Gross examination of the ovaries. Before examination, the preserved ovaries were rinsed in water for $24 \mathrm{~h}$, which was replaced by $70 \%$ ethanol. Females were identified as sexually mature if 1 or more corpora scars were present on the ovaries. Corpora scars present on the ovary were classified into corpora lutea, regressing corpora lutea, and corpora albicantia. Females were classified into 5 reproductive states: (1) sexually immature, (2) pregnant (foetus and a corpus luteum of pregnancy present), (3) pregnant and lactating, (4) sexually mature and lactating, and (5) resting mature (not pregnant or lactating).

Statistical analysis. Age and body length at physical maturity: Three growth models were fitted to lengthat-age data from 510 female Delphinus delphis:

Gompertz

$$
L_{t}=L_{0} e^{\frac{a}{\alpha}\left(1-e^{-\alpha t}\right)}
$$

(Danil \& Chivers 2007) (1)

Double-Gompertz

$$
L_{t}= \begin{cases}L_{0} e^{\frac{a}{\alpha}\left(1-e^{-\alpha t}\right)} & \text { for } t \leq I \\ L_{I} e^{\frac{b}{\beta}\left(1-e^{-\beta(t-I)}\right)} & \text { for } t>I\end{cases}
$$

(Danil \& Chivers 2007) (2)

Richards

$$
L_{t}=L_{\infty}\left(1-b e^{-k t}\right)^{M}
$$

(Richards 1959, Fitzhugh 1976, Innes et al. 1981) (3)

where $L_{t}$ is TBL $(\mathrm{cm})$ at age $t(\mathrm{yr}), L_{0}$ is length at birth (fixed at $93 \mathrm{~cm}$ ), $L_{\infty}$ is asymptotic length, $I$ is the age of intersection of the 2 models in the double-Gompertz growth model, and $a, \alpha, b, \beta, k$ and $M$ are growth 
parameters. We considered ages of intersection, I, from 2 to 10 yr. When fitting the Richards model, $L_{\infty}, k$ and $M$ were estimated while $b$ was calculated as a function of $L_{\infty}, L_{0}$ and $M$. The Richards model was used for descriptive purposes only, so we allowed $M$ to be <1 (Innes et al. 1981), which complicates the biological interpretation of the parameters (Fitzhugh 1976). The 3 models had 2, 5 and 3 estimated parameters, respectively (not including the error parameter). The models were fitted using the optim function of the free statistical software R (R Development Core Team 2007), and minimising a negative normal log-likelihood using the 'L-BFGS-B' method. All parameters were constrained to be positive. We encountered difficulties in obtaining convergence when fitting the double-Gompertz model; therefore, this model was fitted by iterating over fixed $I$ (precision $=0.01$ ), while estimating the remaining parameters. The likelihood surface was relatively uneven in places with respect to $I$, and convergence was sometimes sensitive to initial parameter values. We obtained approximate standard errors (SEs) and 95\% confidence intervals (CIs) for parameter estimates by approximating the variances of the parameter estimates as the diagonal entries of the inverse of the Hessian matrix, returned by optim. These variances were multiplied by $n /(n-p)$ to adjust for the number of estimated parameters $p$ (Fox 2002), and CIs were calculated using the $t$-distribution. Akaike's Information Criterion (AIC) was used to select the model that provided the best balance between fit and estimated number of parameters (including the error parameter).

Average age and body length attained at sexual maturity (ASM): Age and length at maturity were estimated by 2 standard methods:

(1) Sum-of-fraction of immature method. In order to make direct comparisons with other Delphinus delphis life history studies, Hohn's (1989) algorithm for sum-offraction of immature method (SOFI) was used to estimate the ASM and its variance. This method is based on and adapted from DeMaster's $(1978,1984)$ and Cooke's (1984) nonparametric methods.

$$
\begin{gathered}
\mathrm{ASM}=j+\sum_{i=j}^{K} p_{i} \\
\text { Variance }\left(s^{2}\right)=\sum \frac{p_{i} q_{i}}{N_{i}-1}
\end{gathered}
$$

where, if $I_{i} \neq N_{i}, p_{i}=I_{i} / N_{i}$ and $q_{i}=\left(M_{i}\right) / N_{i i}$ if $I_{i}=N_{i}, p_{i}$ $=\left(I_{i}-1 / 2\right) / N_{i}$, and $q_{i}=\left(M_{i}+{ }^{1} / 2\right) / N_{i}$ and if $M_{i}=N_{i}, p_{i}=$ $\left(I_{i}+{ }^{1} / 2\right) / N_{i}$, and $q_{i}=\left(M_{i}-1 /{ }_{2}\right) / N_{i}$.

$$
\mathrm{CI}(\text { at } \mathrm{p}=0.05)=\mathrm{ASM} \pm 1.96 \sqrt{ } s^{2}
$$

$j=$ the first indeterminate age class

$k=$ the last indeterminate age class $p_{i}=$ fraction of immature specimens in age class $i$

$q_{i}=$ fraction of mature specimens in age class $i\left(\mathrm{p}_{i}+\right.$ $\left.\mathrm{q}_{i}=1\right)$

$I_{i}=$ number of immature specimens in age class $i$

$M_{i}=$ number of mature specimens in age class $i$

$N_{i}=$ number of specimens in age class $i\left(N_{i}=I_{i}+M_{i}\right)$

The average length attained at sexual maturity (LSM) was calculated by modifying the SOFI method, using constant length intervals $(5 \mathrm{~cm})$ instead of ages, after Danil \& Chivers (2007).

$$
\begin{gathered}
\mathrm{LSM}=j+\sum_{i=i_{\min }}^{i_{\max }} p_{i} x_{i} \\
\text { Variance }\left(s^{2}\right)=\sum_{i=i_{\min }}^{i_{\max }} \frac{p_{i}\left(1-p_{i}\right) x_{i}}{n_{i}-1}
\end{gathered}
$$

$j=$ the lower limit of the length class with the smallest mature animal

$i_{\min }=$ length class with the shortest mature animal

$i_{\text {max }}=$ length class the longest mature animal

$p_{i}=$ proportion of immature animals in length class $i$

$x_{i}=$ interval width of length class $i$

$n_{i}=$ total number of animals in the $i$ th length class

(2) Generalised linear model. The proportion of females that were sexually mature was described using a generalised linear model with a binomial error distribution and logit link (glm function of R statistical software; R Development Core Team 2007). The age at which $50 \%$ of females were sexually mature (ASM) and its SE were estimated using the dose.p function in the MASS software library for R (Venables \& Ripley 2002). The $95 \%$ CIs for parameters and ASM were calculated using SE and quantiles of the normal distribution. Bootstrapping was used to further quantify uncertainty in parameter estimates: the data were randomly re-sampled with replacement 100000 times, and for each sample of the data the model was re-fitted. The sets of parameter estimates from the fits were then used to calculate mean parameter estimates, SEs and $95 \%$ CIs (from empirical quantiles). ASM (and its SE and $95 \% \mathrm{CI}$ ) was also calculated from the bootstrapped sample of parameter estimates. We deemed the generalised linear model to be the most appropriate method for estimating ASM.

Length of gestation period, foetal growth rate, average date of conception and size at birth: Foetal growth has an initial non-linear phase, followed by a linear phase (Huggett \& Widdas 1951). The length of gestation was calculated using the Huggett \& Widdas (1951) method: total gestation period $T_{\mathrm{G}}=t_{\mathrm{g}}+t_{0}$, where $t_{\mathrm{g}}$ is the linear phase of the gestation period and $t_{0}$ is the nonlinear phase of growth (Ferrero \& Walker 1995). 
The linear phase of growth was calculated by regressing TBL of foetuses and newborn calves $(y)$ on time, indexed by day of year of collection $(x)$.

Unlike Murphy \& Rogan (2006), in which the average length at birth was calculated from tooth sections that either did not have a neonatal line, or where it was just forming, in the current study we estimated size (length and weight) at birth using Börjesson \& Read's (2003) overlap method. This method calculates the mean of overlapping foetal and calf sizes by including the value of the largest non-overlapping foetus $(85 \mathrm{~cm})$ and the smallest non-overlapping calf $(95 \mathrm{~cm})$. Two newborns that both had their umbilical cords attached, and were larger than the smallest non-overlapping calf (96 and $97 \mathrm{~cm})$, were also included in the analysis. The average birth mass was used to estimate the duration of non-linear foetal growth $\left(t_{0}\right)$ using Calder's (1982) equation, $t_{0}=7.25 M_{\text {neo }} 0.19$, where $M_{\text {neo }}$ is the mean mass at birth $(\mathrm{g})$.

The date of conception was estimated for all foetuses and was based on the age of individual foetuses, as described by Börjesson \& Read (2003):

$$
\text { Foetal age }(t)=\left(\frac{L t}{u}\right) \times 30.5+t_{0}
$$

where $t$ is the foetal age in days, $u$ is foetal growth rate $\left(\mathrm{cm} \mathrm{mo}{ }^{-1}\right), L t$ is the actual length of the foetus $(\mathrm{mm})$, 30.5 is the average number of days in a month, and $t_{0}$ is the nonlinear growth rate. Individual conception dates were calculated by subtracting the estimated foetal age ( $t$ in days) from the date found (day of year).

Annual pregnancy rate and calving interval: Assessment of female reproductive status follows the procedures and terminology recommended by the International Whaling Commission (Perrin \& Donovan 1984).

Annual pregnancy rate (APR): APR was estimated by dividing the proportion of pregnant females in the sexually mature sample by the length of gestation, expressed in years:

$$
\mathrm{APR}=\frac{P}{T_{\mathrm{G}}}
$$

where $T_{\mathrm{G}}=$ length of gestation, and $P=$ proportion of sample pregnant (including individuals that were pregnant and lactating). Samples obtained during the mating period were not included in this analysis, due to the increased possibility that embryos or small foetuses were not detected during early stages of gestation.

Calving interval (Cal): The calving interval is an estimate of the period between parturition in mature females. It was calculated as the inverse of the APR:

$$
\mathrm{Cal}=\frac{1}{\mathrm{APR}}
$$

Control study. The control group was composed of short-beaked common dolphins that stranded along the UK coastline and were diagnosed as incidentally bycaught (i.e. they died as a result of entanglement in fishing gear) according to specific diagnostic criteria outlined by Kuiken et al. (1994). During standard postmortem procedures, gross examinations of all major organs were carried out. Following this, histological, bacteriological or virological examinations (or a combination of these) were undertaken on a range of routine tissue samples and any gross lesions that were found, depending on the suspected etiology (further outlined by Law 1994, Jepson 2005). For the purpose of this study, each dolphin was categorised into 1 of 3 health status categories (1) healthy individuals, (2) health mildly compromised but still capable of successfully reproducing, and (3) individuals suffering from severe (and potentially fatal) infectious or non-infectious disease. Nutritional condition was also assessed for each individual, as nutrition can affect rates of ovulation, pregnancy, length of lactation, neonate size, calving interval, age at first reproduction, growth rate, birth rate and survival of young (Lockyer 1990). During post-mortem examinations, individuals were classified either in good, moderate or poor nutritional condition. Only individuals classified as healthy, in good nutritional condition and not suffering from any infectious or non-infectious diseases that might inhibit reproduction were included in the control group.

Variations in the reproductive parameters with age. In order to investigate evidence of senescence in the population, i.e. the presence of post-reproductive females, we estimated the proportion of pregnant, lactating and resting mature females for 4 different age classes: (1) $\leq 10$, (2) 11-15, (3) 16-20 and (4) > $20 \mathrm{yr}$ old.

Temporal variations in life history parameters. We assessed evidence of density-dependent responses by investigating temporal variations in proportion pregnant, ASM and nutritional condition. The sample was divided into 2 time periods: 1991 to 1999 and 2000 to 2006. These time periods were selected as large-scale incidental mortalities in tuna driftnet fisheries were reported during the 1990 s, which subsequently led to a ban on driftnets in 2002 (see Rogan \& Mackey 2007, and references therein). A generalised linear model approach was used to estimate the mean difference in the ASM between decades, along with their CIs.

Power analysis. Statistical power analysis was used to determine the probability of detecting a change in the pregnancy rate between 2 time periods, using data available in the current study. Power was calculated using the power.prop.test function in R. We determined the power to detect significant decreases and increases in the proportion of pregnant females in 
the population given different sample sizes $(50,100$ and 150 for each time period). We assumed that sample size was the same in both time periods, the initial pregnancy rate was 0.25 and a 2-tailed significance level of 0.05 . We considered a power $\geq 80 \%$ to be adequate.

\section{RESULTS}

The sample. The distribution of the sampling locations (stranding and bycatch data) for female Delphinus delphis whose gonads were analysed in this study is shown in Fig. 1. TBL of the entire dataset ranged from 91 to $239 \mathrm{~cm}(\mathrm{n}=930)$, with a modal size class of 190 to 199 cm (Fig. 2a). Age was determined for 515 female D. delphis, and age ranges for an additional 23 individuals. Female $D$. delphis ranged in age from 0 to $29 \mathrm{yr}$ (Fig. 2b). In the sample of 610 female $D$. delphis for which sexual maturity status was determined, $49.5 \%$ were classified as sexually immature and $50.5 \%$ as sexually mature. The mature sample was composed predominately of resting mature females $(57.3 \%$, see Table 1$)$. Where data on maturity status were available, body weight (excluding individuals that were identified as pregnant) ranged from 8 (newborn) to $129 \mathrm{~kg}(\mathrm{n}=133)$, and all sexually mature females were $>66.5 \mathrm{~kg}$ (see Fig. 3).

Age and body length at physical maturity. Asymptotic length $\left(L_{\infty}\right)$ was estimated as $197 \mathrm{~cm}, 201 \mathrm{~cm}$ and $202 \mathrm{~cm}$ for the Gompertz, double-Gompertz and Richards models, respectively (Table 2). AIC values for the Gompertz, double-Gompertz and Richards models were 4030, 3922 and 3914, respectively. This indicated that the double-Gompertz and Richards models provided substantially better fits than the Gompertz model (Fig. 4), and that the 1 additional parameter of the Richards model was sufficient to capture the trend in the data, compared to the 3 additional parameters in the double-Gompertz model (Burnham \& Anderson 2002). The fixed age of intersection (I) that resulted in the highest likelihood for the double-Gompertz model was $2 \mathrm{yr}$, i.e. the lower limit of the range considered (Table 2). The likelihood of the double-Gompertz model generally decreased with increasing $I$. The Richards model provided a more parsimonious model to describe growth in body length with age.

Average age (ASM) and body length (LSM) at attainment of sexual maturity. Sexually immature Delphinus delphis ranged from 91 to $210 \mathrm{~cm}$ TBL $(\mathrm{n}=294)$, and 0 to 12 yr old $(\mathrm{n}=190)$. Sexually mature $D$. delphis ranged from 165 to $227 \mathrm{~cm} \mathrm{TBL}(\mathrm{n}=303)$ and 6.5 to 26 yr $(\mathrm{n}=189)$.

(1) SOFI method: 379 females of known maturity status and age were included in the SOFI method, and an ASM of $8.66 \mathrm{yr}$ (SE = 0.03) was determined. Indeterminate age classes ranged between 6 and $12 \mathrm{yr}$
(Table 3). The estimated ASM using the Iberian data was $8.83 \mathrm{yr}, 9 \mathrm{yr}$ for the Irish, $9.25 \mathrm{yr}$ for the UK and $8.55 \mathrm{yr}$ for the French data. It should be noted that with the SOFI method, the ASM is biased downward, since the age data are effectively rounded down to the nearest integer.

Using the modified SOFI method, and $5 \mathrm{~cm}$ body length classes $\left(X_{i}\right)$, the LSM was estimated to be 188.8 $\mathrm{cm}(\mathrm{SE}=0.02$, Table 3).

(2) Logistic regression: A similar LSM value was obtained when a logistic curve $y=\frac{a}{1+\left(\frac{x}{x_{0}}\right)^{b}}$ was fitted to the data. The body length at which $50 \%$ of the sample was sexually mature was $188.2 \mathrm{~cm}\left(x_{0}\right)$, where $a=1$ and $b=-28.2\left(\mathrm{R}^{2}=0.96,<0.0001\right)$.

(3) Generalised linear model: ASM was estimated to be $8.22 \mathrm{yr}(\mathrm{SE}=0.263$ ) with a $\mathrm{CI}$ of 7.71 to 8.74 (Table 4, Fig. 5). Interestingly, the bootstrapped estimate was very similar, mean 8.23 yr $(\mathrm{SE}=0.27$, $\mathrm{CI}=7.70$ to 8.76 ), which suggests an advantage to using the non-bootstrapped, less computationallyintensive method.

Size at birth. The sample sizes for calculating average length and weight at birth were small, and the average weight at birth of $8700 \mathrm{~g}$ was calculated

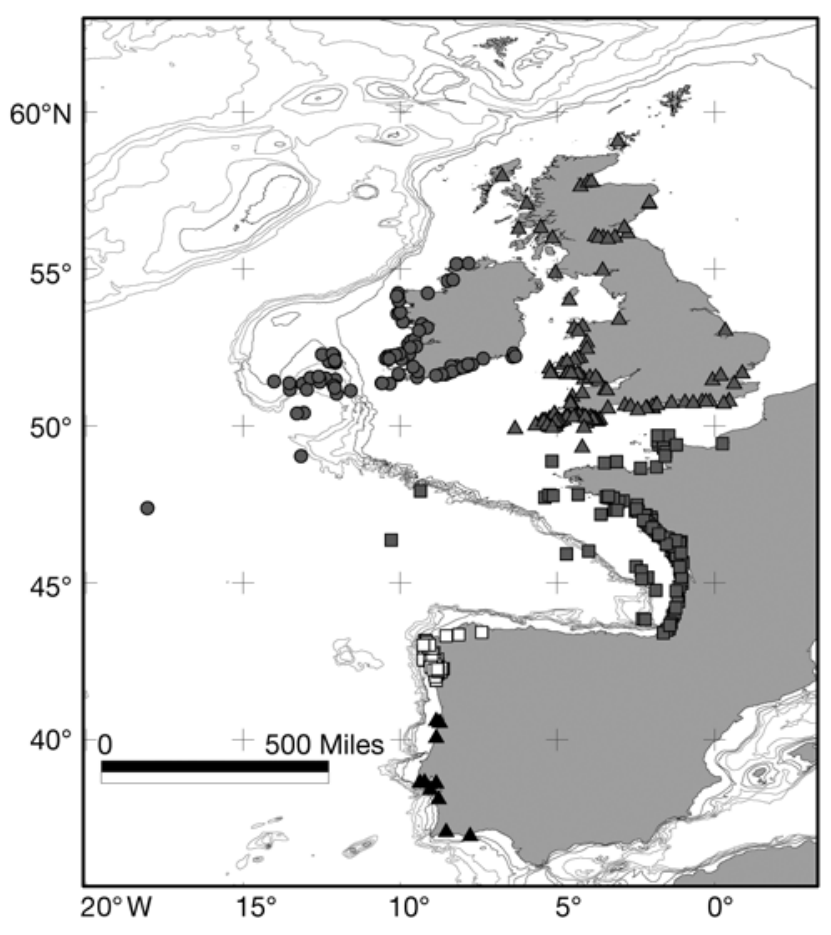

Fig. 1. Delphinus delphis. Distribution of sampling locations of female in the North-east Atlantic. Samples were predominantly obtained from Irish stranding and bycatch projects $(O)$, UK stranding project $(\Delta)$, French stranding and bycatch projects $(\square)$, Galician stranding project $(\square)$, and Portuguese stranding project $(\mathbf{\Delta})$ 

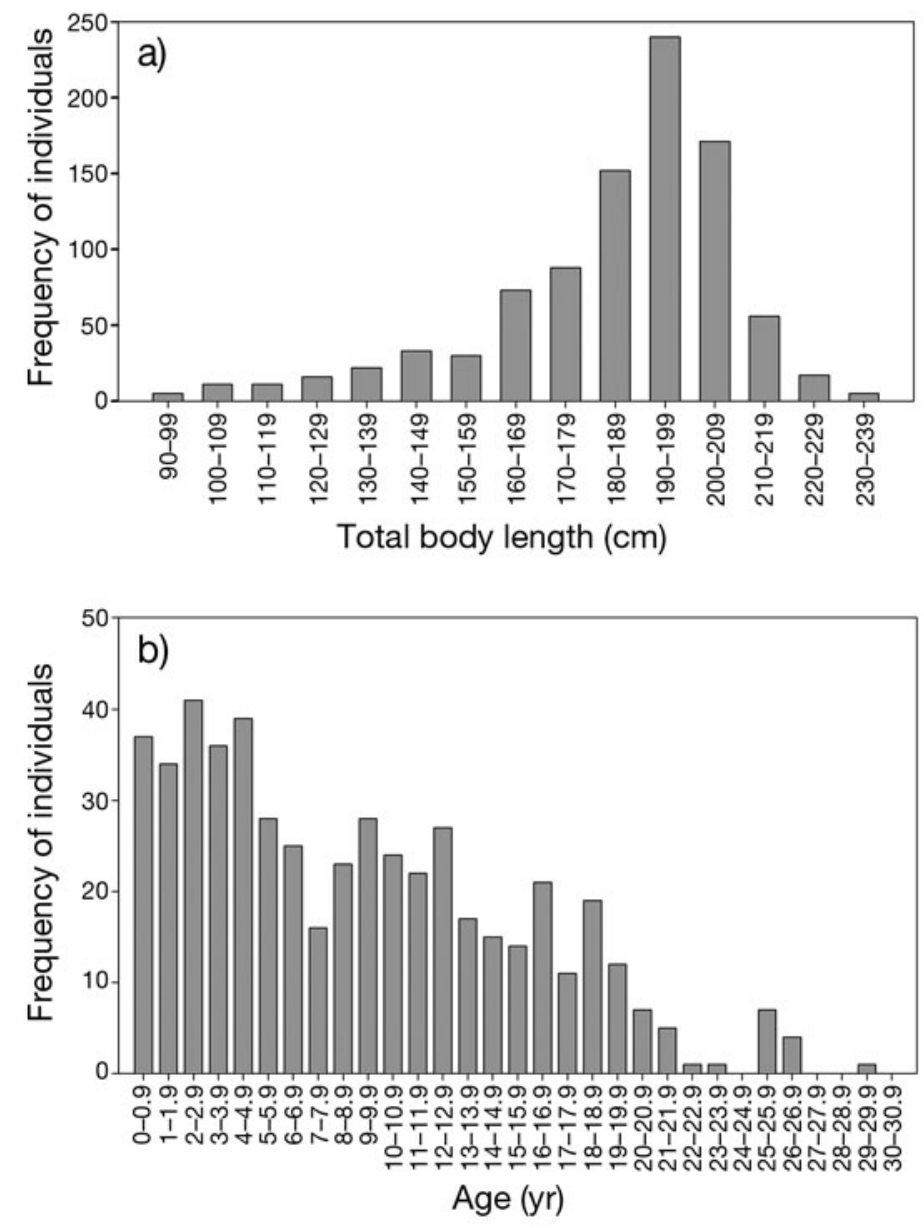

Fig. 2. Delphinus delphis. Frequency distributions for (a) total body length $(\mathrm{n}=930)$, (b) age $(\mathrm{n}=515)$

using a sample size of only 2 individuals. The average length at birth was calculated to be $93 \mathrm{~cm}$ ( $\mathrm{n}=7$ ).

Length of gestation period. The linear foetal growth phase of the gestation period was estimated to be $322.1 \mathrm{~d}$. This was calculated by regressing foetal and newborn length on day of year $(y=0.2887 x-73.154$, $\left.\mathrm{r}^{2}=0.89, \mathrm{n}=36, \mathrm{p}=0.000\right)$, substituting the average length at birth $(93 \mathrm{~cm})$ into the equation, and assuming that foetal length $=0$ at the initial stage of this phase. Using Calder's (1982) equation, the length of the nonlinear foetal growth phase was estimated as $40.6 \mathrm{~d}$ $\left[t_{0}=7.25(8700)^{0.19}\right]$. Summing the linear and nonlinear gestation periods together produced a total gestation period of $362.7 \mathrm{~d}$ or $0.99 \mathrm{yr}\left(T_{\mathrm{G}}=322.1+40.6 \mathrm{~d}\right)$.

Foetal growth. Foetal growth rate was calculated by regressing average TBL on month, and an estimate of $8.2 \mathrm{~cm} \mathrm{mo}^{-1}$ was obtained.
Table 1. Delphinus delphis. Reproductive status of all sexually mature females from the NE Atlantic (1990 to 2006), with comparisons to mature female dolphins from the eastern tropical Pacific (ETP; 1975 to 1993, data from Danil \& Chivers 2007). Categories: pregnant (foetus and a corpus luteum of pregnancy present); simultaneously pregnant and lactating, sexually mature and lactating, and resting mature individuals that were not pregnant or lactating

\begin{tabular}{|lccccc|}
\hline \multirow{2}{*}{ Reproductive status } & \multicolumn{2}{c}{ NE Atlantic } & \multicolumn{2}{c|}{ ETP - ETP } \\
& $\mathrm{n}$ & $\%$ & $\mathrm{n}$ & $\%$ \\
\hline Pregnant & 58 & 19.2 & 83 & 24.9 \\
Pregnant and lactating & 18 & 6 & 65 & 19.5 \\
Lactating & 53 & 17.5 & 149 & 44.8 \\
Resting mature & 173 & 57.3 & 36 & 10.8 \\
Total & 302 & 100 & 333 & 100 \\
\hline
\end{tabular}

Average date of conception. The average day of conception was calculated as day-of-year 200 or 19 July $(\mathrm{n}=36$ ). Individual conception dates ranged from 5 April to 2 October, with the majority of individuals conceived in July (42\%).

Annual pregnancy rate (APR).The sample for estimating the pregnancy rate, collected between 1990 and 2006, was composed of 248 sexually mature females, of which 65 were pregnant. Taking the gestation period as $0.99 \mathrm{yr}$, the APR in the sample was estimated at ca. $26 \%(26 / 0.994)$. Table 5 presents the pregnancy rate information for each area sampled in the current study, and within the study area the pregnancy rate varied from $19 \%$ (Iberia, n = 32 mature females) to $29 \%$ (France, $n=98$ mature females), although no significant difference was obtained between areas in the proportion of pregnant females.

Calving interval (Cal). Calculated as the inverse of the APR, the overall calving interval was estimated as $3.79 \mathrm{yr}$ or $45.5 \mathrm{mo}$ for the ENA population.

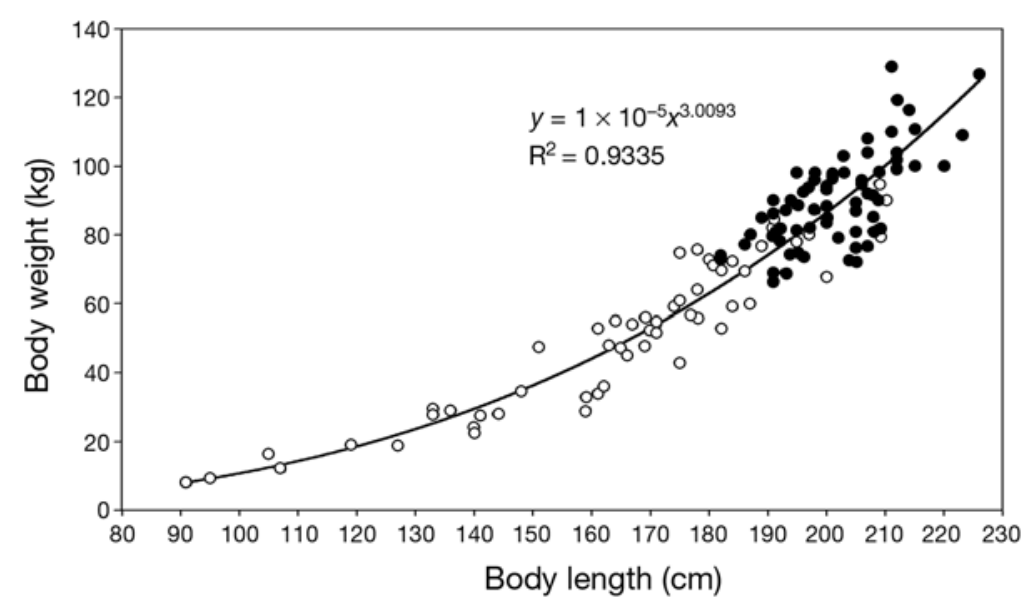

Fig. 3. Delphinus delphis. Body weight against body length $(\mathrm{n}=$ 133). Sexually immature (O) and mature $(\bullet)$ females 
Table 3. Delphinus delphis. Sum-of-fraction of immature (SOFI) method for estimating the average age and body length at sexual maturity in the NE Atlantic females. Imm: immature. Mat: mature

\begin{tabular}{|lcccccc|}
\hline $\begin{array}{l}\text { Age } \\
\text { class } \\
\text { yr) }\end{array}$ & $\begin{array}{c}\text { Imm } \\
(\mathrm{n})\end{array}$ & $\begin{array}{c}\text { Mat } \\
(\mathrm{n})\end{array}$ & $\begin{array}{c}\text { Total in } \\
\text { age class } \\
\left(N_{i}\right)\end{array}$ & $\begin{array}{c}\text { Fraction } \\
\text { imm } \\
\left(p_{i}\right)\end{array}$ & $\begin{array}{c}\text { Fraction } \\
\text { mat } \\
\left(q_{i}\right)\end{array}$ & $\begin{array}{c}\left(p_{i} q_{i}\right) \\
N_{i}-1\end{array}$ \\
\hline 6 & & & 13 & 0.92 & 0.08 & 0.01 \\
7 & 12 & 1 & 13 & 0.70 & 0.30 & 0.02 \\
8 & 7 & 3 & 10 & 0.40 & 0.60 & 0.02 \\
9 & 6 & 9 & 15 & 0.19 & 0.81 & 0.01 \\
10 & 3 & 13 & 16 & 0.33 & 0.67 & 0.01 \\
11 & 6 & 12 & 18 & 0.06 & 0.94 & 0.00 \\
12 & 1 & 17 & 18 & 0.06 & 0.94 & 0.00 \\
& 1 & 17 & 18 & & & \\
Length & Imm & Mat & Total in & Fraction & Fraction & $\left(p_{i} q_{i} X_{i}\right)$ \\
Class & $(\mathrm{n})$ & $(\mathrm{n})$ & length class & imm & mat & $N_{i}-1$ \\
$(\mathrm{~cm})$ & & & $\left(N_{i}\right)$ & $\left(p_{i}\right)$ & $\left(q_{i}\right)$ & \\
\hline $165-169$ & 26 & 1 & 27 & 0.96 & 0.04 & 0.01 \\
$170-174$ & 26 & 1 & 27 & 0.96 & 0.04 & 0.01 \\
$175-179$ & 21 & 3 & 24 & 0.88 & 0.13 & 0.02 \\
$180-184$ & 35 & 11 & 46 & 0.76 & 0.24 & 0.02 \\
$185-189$ & 19 & 18 & 37 & 0.51 & 0.49 & 0.03 \\
$190-194$ & 18 & 48 & 66 & 0.27 & 0.73 & 0.02 \\
$195-199$ & 14 & 68 & 82 & 0.17 & 0.83 & 0.01 \\
$200-204$ & 6 & 58 & 64 & 0.09 & 0.91 & 0.01 \\
$205-209$ & 6 & 49 & 55 & 0.11 & 0.89 & 0.01 \\
$210-214$ & 1 & 24 & 25 & 0.04 & 0.96 & 0.01 \\
\hline
\end{tabular}

The estimated LSM using the adjusted SOFI method was estimated as $190.3 \mathrm{~cm}(\mathrm{SE}=0.04)$ for the $1990 \mathrm{~s}$ and $187.4 \mathrm{~cm}(\mathrm{SE}=0.04)$ for the 2000s.

Overall, there was no significant difference in the nutritional condition of individuals between the 1990s (63\% good, $29 \%$ moderate, $8 \%$ poor nutritional condition, $\mathrm{n}=108$ ) and the 2000s (55\% good, $37 \%$ moderate, $8 \%$ poor nutritional condition, $\mathrm{n}=218$ ), with only an $8 \%$ increase in the number of individuals in moderate condition $\left(\chi^{2}=0.30\right.$, $\mathrm{df}=1, \mathrm{p}=$ 2.39).

Power analysis. A sample size of 150 females provides a statistical power $\geq 80 \%$ to detect an absolute decrease $\geq 13 \%$ in pregnancy rate between 2 time periods, whereas a sample size of 100 females would be sufficient to detect a decrease $\geq 15 \%$ (Fig. 8). A sample size of 50 females, however, would only detect a decrease $\geq 20 \%$ with a power $\geq 80 \%$ (pregnancy rate in second time period $\leq 0.05$ ). In contrast, if an increase occurred in the pregnancy rate, a sample size of 150 females would be needed to detect $\mathrm{a} \geq 15 \%$ increase in the pregnancy rate at a power of $\geq 80 \%$. the highly significant relationship between age and the proportion of females that were sexually mature. The estimated ASM was higher in a model fitted to only the 1990 s data ( $8.79 \mathrm{yr}$ ) than in a model fitted to only the 2000s data (7.94 yr), but their 95\% CIs overlapped (Table 4, Fig. 7). Furthermore, the bootstrapped 95\% CI for the mean difference in ASM between separate models for the 1990s and 2000s was -0.23 to 1.96 , indicating that this was not significantly different from 0 at $\alpha=$ 0.05 . Overall, these results suggest that there were no significant differences in the ASM between decades.

\section{DISCUSSION}

\section{Female reproductive parameters in the ENA and other Delphinus delphis populations}

Reproductive seasonality

The timing of parturition tends to be highly synchronised in populations of mammals at high latitudes where seasons of high productivity are brief and less synchronised, and more protracted in low-latitude

Table 4. Delphinus delphis. Estimates from generalised linear models describing age at sexual maturity (binomial error distribution, logit link). Parameters are on the scale of the link function. ASM: estimated age at which $50 \%$ of animals were sexually mature

\begin{tabular}{|c|c|c|c|c|c|c|c|}
\hline \multirow[t]{2}{*}{ Data } & \multirow[t]{2}{*}{ Parameter/ASM } & \multirow[t]{2}{*}{ Estimate } & \multirow[t]{2}{*}{$\mathrm{SE}$} & \multirow[t]{2}{*}{$95 \% \mathrm{CI}$} & \multicolumn{3}{|c|}{ - Bootstrapped } \\
\hline & & & & & Mean & SE & $95 \% \mathrm{CI}$ \\
\hline \multirow[t]{3}{*}{ All } & Intercept & -7.96 & 1.09 & $-10.1,-5.81$ & -8.21 & 0.97 & $-10.5,-6.69$ \\
\hline & Slope & 0.97 & 0.13 & $0.72,1.22$ & 1.0 & 0.12 & $0.81,1.29$ \\
\hline & ASM & 8.22 & 0.26 & 7.71, 8.74 & 8.23 & 0.27 & $7.70,8.76$ \\
\hline \multirow[t]{3}{*}{$1990 \mathrm{~s}$} & Intercept & -11.7 & 3.54 & $-18.7,-4.80$ & -24.9 & 49.4 & $-174,-8.77$ \\
\hline & Slope & 1.34 & 0.40 & $0.55,2.12$ & 2.90 & 5.90 & $0.98,20.8$ \\
\hline & ASM & 8.79 & 0.41 & $7.99,9.59$ & 8.79 & 0.45 & $7.99,9.71$ \\
\hline \multirow[t]{3}{*}{$2000 \mathrm{~s}$} & Intercept & -7.09 & 1.11 & $-9.27,-4.91$ & -7.38 & 1.01 & $-9.76,-5.87$ \\
\hline & Slope & 0.89 & 0.13 & $0.64,1.15$ & 0.93 & 0.14 & $0.73,1.26$ \\
\hline & ASM & 7.94 & 0.33 & $7.29,8.59$ & 7.95 & 0.33 & $7.30,8.60$ \\
\hline
\end{tabular}


populations (Börjesson \& Read 2003). This enables calves to be born when maternal prey is abundant and of high quality (Urian et al. 1996, Börjesson \& Read 2003). Short-beaked common dolphins in the current study exhibited a seasonal pattern of reproduction that was intermediate between the highly synchronised births of harbour porpoises, where most births occur over a few weeks (Börjesson \& Read 2003), and the extended parturition season of tropical odontocetes, e.g. Stenella spp. and Delphinus delphis, which exhibit both diffuse and bimodal patterns of seasonality (Barlow 1984, Danil \& Chivers 2007). A unimodal summer calving period has been identified for $D$. delphis in the ENA, and the mating period was found to extend over ca. 5 mo from May to September, inclusive, with possibly a more active period in July and August (Murphy 2004, Murphy et al. 2005, this study). In the WNA, conception and parturition were only reported during July and August (Westgate \& Read 2007). The protracted parturition and mating period in the ENA may reflect the sampling of individuals that were sexually active in the outer limits of the breeding season and the smaller sample sizes and/or sampling biases of the WNA study.

A distinct seasonal peak in parturition was also identified in mid-May to early June in the North Pacific Ocean based on regressions of length on day of year for foetuses and calves $\leq 115 \mathrm{~cm}$ in body length (Ferrero \& Walker 1995). The authors were not able to properly determine the length of the breeding season in this population, due to small sample sizes of neonates, preg-

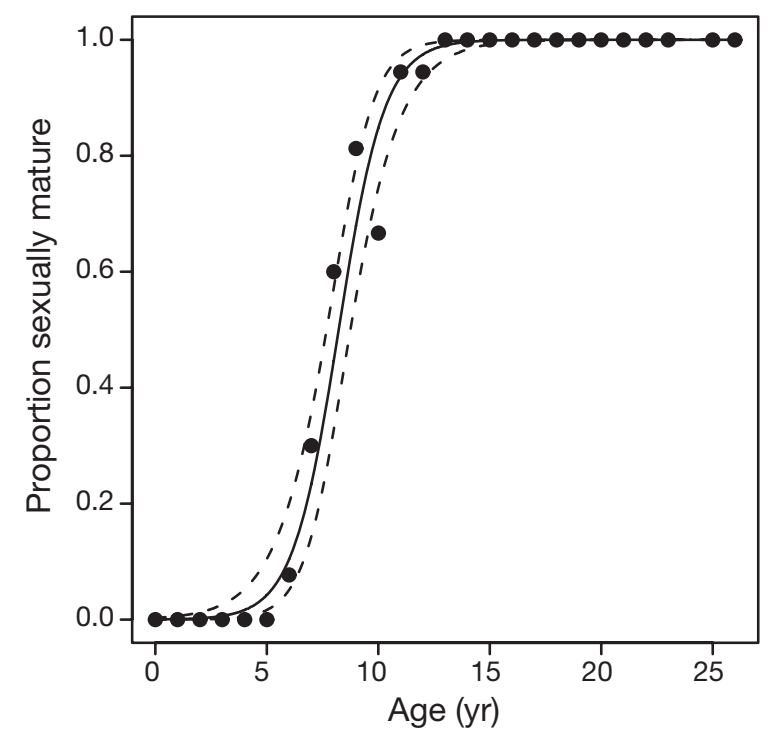

Fig. 5. Delphinus delphis. Proportion of females that were sexually mature by age $(n=379)$. Solid line: mean estimated proportion mature from a generalised linear model (binomial error distribution; Table 4). Dashed lines: approximate 95\% CIs calculated from estimated SEs and quantiles of the normal distribution on the scale of the link function and then transformed to the response scale nant females with near-term foetuses and lactating females. In South African waters, parturition in common dolphins - described initially as Delphinus delphis by Mendolia (1989) but later as D. capensis by Best (2007, and references therein) - occurs during the austral summertime, with a peak in calving in February and March. Mating was reported during March and April, although conception outside this period also occurred (Mendolia 1989, Best 2007). In the eastern North Pacific, the northern (off southern California, USA, north of approx 13 to $18^{\circ} \mathrm{N}$ ) and southern (south of approx $2^{\circ} \mathrm{N}$ ) stocks of $D$. delphis exhibit a bimodal calving season, whereas parturition was distributed evenly throughout the year for the central eastern tropical Pacific stock (Evans 1975, Perryman \& Lynn 1993, Danil \& Chivers 2007). It is believed that the upwelling region inhabited by $D$. delphis in the eastern tropical Pacific (ETP) may provide an environment that is more stable throughout the year, therefore enabling females to meet the energetic demands of year-round parturition (Danil \& Chivers 2007). Overall reproductive seasonal-

Table 5. Delphinus delphis. Annual pregnancy rate (APR) and calving intervals (Cal) estimated for the NE Atlantic population, excluding individuals that died during the mating/calving period (May to September). NA = not analysed. Mat: mature. Preg: pregnant. ASM: average age at sexual maturation, LSM: average length at sexual maturity

\begin{tabular}{|c|c|c|c|c|c|c|}
\hline $\begin{array}{l}\text { Data } \\
\text { origin }\end{array}$ & $\begin{array}{l}\text { Mat } \\
\text { (n) }\end{array}$ & $\begin{array}{l}\text { Preg } \\
\text { (n) }\end{array}$ & $\begin{array}{c}\text { APR } \\
(\%)\end{array}$ & $\begin{array}{l}\text { Cal } \\
(\mathrm{yr})\end{array}$ & $\begin{array}{c}\mathrm{ASM}(\mathrm{SE}) \\
\mathrm{n}\end{array}$ & $\begin{array}{c}\text { LSM (SE) } \\
n\end{array}$ \\
\hline UK & 93 & 26 & 28 & 3.56 & $\begin{array}{c}9.25 \\
(0.21) \\
64\end{array}$ & $\begin{array}{c}188.1 \\
(0.05) \\
177\end{array}$ \\
\hline French & 98 & 28 & 29 & 3.48 & $\begin{array}{c}8.55 \\
(0.06) \\
170\end{array}$ & $\begin{array}{c}193.55 \\
(0.06) \\
190\end{array}$ \\
\hline Irish & 25 & 5 & 20 & 4.97 & $\begin{array}{c}9.00 \\
(0.29) \\
65\end{array}$ & $\begin{array}{c}187.5 \\
(0.19) \\
77\end{array}$ \\
\hline Iberian & $32^{\mathrm{a}}$ & 6 & 19 & 5.3 & $\begin{array}{c}8.83 \\
(0.09) \\
80^{\mathrm{b}}\end{array}$ & $\begin{array}{c}186.8 \\
(0.11) \\
153\end{array}$ \\
\hline $\begin{array}{l}\mathrm{NE} \\
\text { Atlantic }\end{array}$ & 248 & 65 & 26 & 3.79 & $\begin{array}{c}8.22^{\mathrm{c}} \\
(0.26) \\
379\end{array}$ & $\begin{array}{c}188.8 \\
(0.02) \\
597\end{array}$ \\
\hline $\begin{array}{l}\text { Control } \\
\text { study }\end{array}$ & 46 & 15 & 33 & 3.05 & NA & $\begin{array}{c}191.6 \\
(0.12) \\
80\end{array}$ \\
\hline $1990 \mathrm{~s}$ & 83 & 20 & 24 & 4.13 & $\begin{array}{c}8.79^{\mathrm{c}} \\
(0.41) \\
110\end{array}$ & $\begin{array}{c}190.3 \\
(0.04) \\
257\end{array}$ \\
\hline $2000 \mathrm{~s}$ & 165 & 45 & 27 & 3.64 & $\begin{array}{c}7.94^{\mathrm{C}} \\
(0.33) \\
269\end{array}$ & $\begin{array}{c}187.4 \\
(0.04) \\
340\end{array}$ \\
\hline \multicolumn{7}{|c|}{$\begin{array}{l}\text { a Only } 3 \text { mature females from Portugal were included in } \\
\text { the pregnancy rate calculations } \\
\text { bNo age data included from Portugal } \\
\text { 'Using the generalised linear model (non-bootstrapped) } \\
\text { approach }\end{array}$} \\
\hline
\end{tabular}


Table 6. Delphinus delphis. Proportion of pregnant, pregnant and lactating, lactating and resting mature females within different age groups

\begin{tabular}{|lccccccccc|}
\hline \multirow{2}{*}{ Females } & \multicolumn{2}{c}{$\leq 10 \mathrm{yr}$} & \multicolumn{2}{c}{$11-15 \mathrm{yr}$} & \multicolumn{2}{c}{$16-20 \mathrm{yr}$} & \multicolumn{2}{c}{$>20 \mathrm{yr}$} \\
& $\mathrm{n}$ & $\%$ & $\mathrm{n}$ & $\%$ & $\mathrm{n}$ & $\%$ & $\mathrm{n}$ & $\%$ \\
\hline Pregnant only & 6 & 17 & 12 & 18 & 10 & 17 & 4 & 17 \\
Pregnant and lactating & 3 & 8 & 8 & 12 & 3 & 5 & 0 & 0 \\
Lactating only & 4 & 11 & 9 & 13 & 11 & 19 & 5 & 20 \\
Resting mature & 23 & 64 & 39 & 57 & 34 & 59 & 15 & 63 \\
Total & 36 & 100 & 68 & 100 & 58 & 100 & 24 & 100 \\
All pregnant & 9 & 25 & 20 & 29 & 13 & 22 & 4 & 17 \\
(including lactating) & & & & & & & & \\
\hline
\end{tabular}

ity was strongest in the southern stock, which has the widest range of oceanographic conditions of all 3 stocks (Au \& Perryman 1985, Perryman \& Lynn 1993).

Average age and body length at attainment of sexual maturity

Geographical variations in the ASM and LSM were observed between data produced by the current study and those previously published on other common dolphin populations (see Table 7). Within the ENA, sexually immature females from Delphinus delphis bycaught in the French tuna fishery (operating in the area encompassing $44^{\circ}$ to $51.5^{\circ} \mathrm{N}$ and from the Bay of Biscay region $-6^{\circ}$ to $-21^{\circ} \mathrm{W}$ ) ranged in body length from 100 to $194 \mathrm{~cm}$, and sexually mature ones from 185 to $208 \mathrm{~cm}$, or from 0 to $11 \mathrm{yr}$ and 10 to $23 \mathrm{yr}$, respectively (Goujon et al. 1993). Although the sample size in the study by Goujon et al. (1993) was small, their results are comparable with those of the current study;

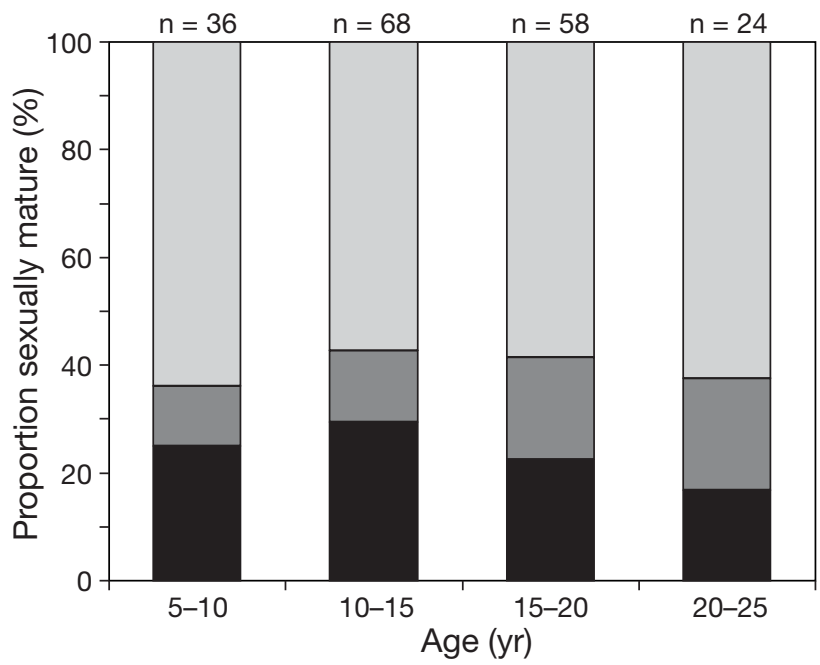

Fig. 6. Delphinus delphis. Proportion of pregnant (black), lactating (dark grey) and resting (light grey) mature females against age. Samples sizes in parentheses both studies suggest that sexual maturity is attained at an age older than that previously reported by Collet (1981) of 5 to 7 yr. Collet's (1981) estimate was determined by regressing age on body length data, and establishing the age at which individuals attained a body length of $190 \mathrm{~cm}$ (all sexually immature individuals were $<190 \mathrm{~cm}$, and mature $>190 \mathrm{~cm})$. Thus, the results obtained are not directly comparable to this study.

\section{Pregnancy rates}

The estimated APR for the ENA population was $26 \%$ ( $\mathrm{n}=248$ ), and results suggest that Delphinus delphis in this population have a similar pregnancy rate to animals inhabiting WNA waters. Westgate \& Read (2007) estimated a pregnancy rate of $28 \%$ (Table 7 ), although the sample size in their study was small and mature females that died during the calving/mating period were not excluded from the analysis. Mendolia (1989) assessed the reproductive status of 93 mature female long-beaked common dolphins off South Africa, 37 of which were pregnant. Using these data, an APR of $40.2 \%$ can be estimated, which is significantly different from the ENA population $\left(\chi^{2}=5.95\right.$, df $\left.=1, p=0.02\right)$. In the ETP, Danil \& Chivers (2007) estimated a much higher pregnancy rate for $D$. delphis of $47 \%$.

It has been reported in other small delphinid species that most foetal mortality occurs in the first trimester (40 to $67 \%$ ) and following this, the foetal mortality rate decreases significantly; total mortality from conception to birth ranges from 78 to $87 \%$ (Perrin et al. 2003). The possibility of sampling females that aborted during the initial stages of pregnancy in the current study was reduced by excluding individuals that were sampled during the mating/breeding season (May to September). In addition, $88 \%$ of the sample was obtained during the period December to March, the second trimester. Perrin et al. (2003) attributed the high foetal mortality rate in Stenella longirostris and $S$. attenuata to adverse interactions with purse seine fisheries in the ETP, by induction of miscarriage due to physiological stress of chase and capture or indirectly through depletion of energy stores. This type of fishing activity in the ENA is not associated with the high rates of incidental capture observed for small delphinids in the ETP, and therefore the estimated pregnancy rate in the current study should give an indication of the actual birth rate in the ENA Delphinus delphis population. 


\section{Breeding cycle}

The cetacean breeding cycle has 3 parts: gestation, lactation and resting or anoestrous period. Collet's (1981) initial study on Delphinus delphis off the French Atlantic coast proposed a minimum calving interval of 2 yr. In the current study, a gestation period of $0.99 \mathrm{yr}$ and a calving interval (1/APR method) of $3.79 \mathrm{yr}$ were calculated. This is similar to Murphy's (2004) earlier study, which estimated a pregnancy rate of $28 \%$, a calving internal of $42.55 \mathrm{mo}$ (3.55 yr), a lactation period of $10.35 \mathrm{mo}$ and a resting period of $20.7 \mathrm{mo}$ for $D$. delphis off the Irish coast. Note that Murphy's (2004) study on life history parameters in female common dolphins

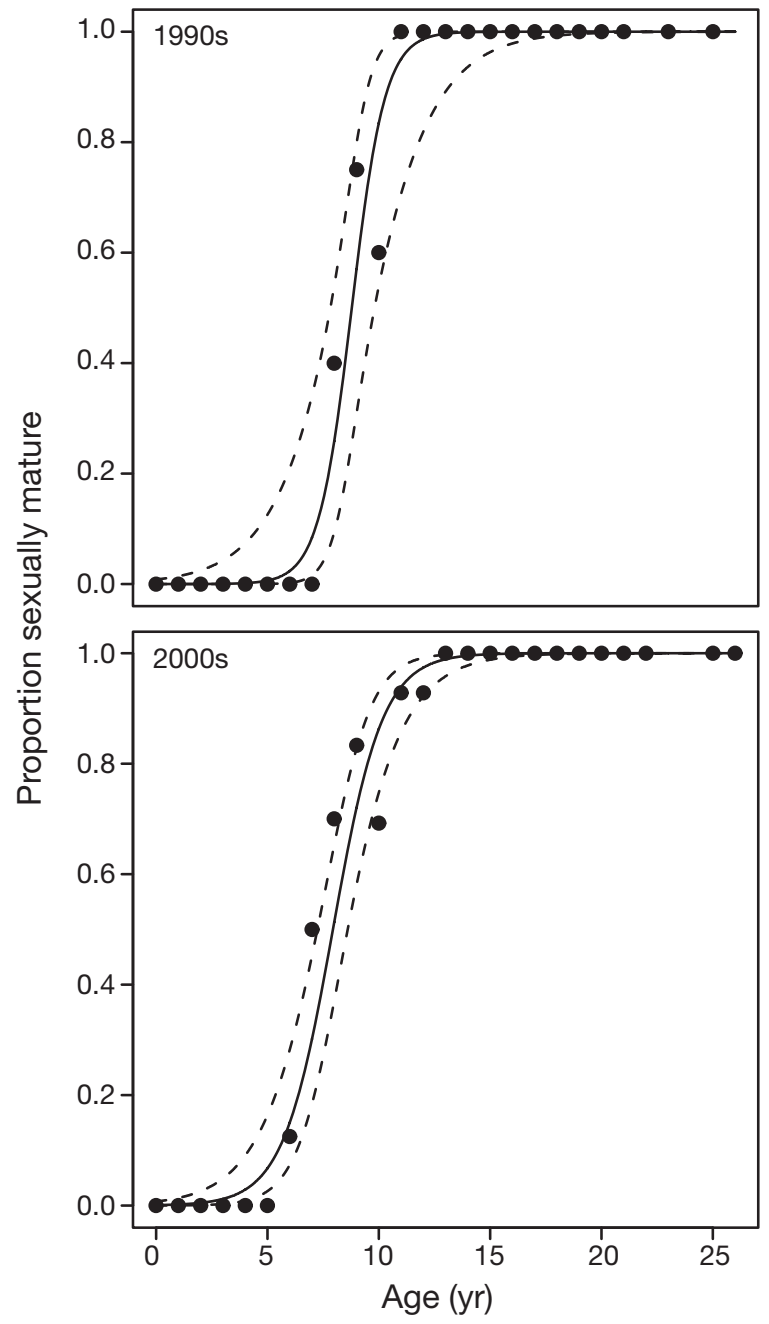

Fig. 7. Delphinus delphis. Proportion of females from the 1990s $(\mathrm{n}=110)$ and 2000s $(\mathrm{n}=269)$ that were sexually mature by age. Solid lines: mean estimated proportion mature from generalised linear models (binomial error distribution; Table 4). Dashed lines: approximate $95 \%$ CIs calculated from estimated SEs and quantiles of the normal distribution on the scale of the link function and then transformed to the response scale off the Irish coast (data also used in the current analysis) estimated the calving interval by summing up gestation, lactation and resting periods. Due to the small sample size in this study ( $\mathrm{n}=36$ mature females), all sexually mature females were included in the analysis for estimating the pregnancy rate and calving interval (i.e. including females that died during the mating and calving seasons). Each female was assessed for pregnancy based on gross and histological examination of the ovaries and gross examination of the uteri, which allowed discrimination between ovulating, just pregnant and recently pregnant females.

The extended calving interval identified in the ENA was a result of the high proportion of resting mature females, which extended the length of the resting period. Danil \& Chivers (2007) determined a shorter calving interval of $2.1 \mathrm{yr}$ in the ETP, due to a very short resting period of $2.8 \mathrm{mo}$. Not only was a very small proportion of individuals actually resting in the ETP sample, but also $19.5 \%$ of the mature sample was simultaneously pregnant and lactating, compared to $6 \%$ in the ENA (see Table 1). Mendolia (1989) calculated a calving interval of just over $2 \mathrm{yr}$ for long-beaked common dolphins off South Africa based on the sum of phases approach, a gestation period of 10 to $11 \mathrm{mo}$, a lactation period of ca. $8.8 \mathrm{mo}$ (range 6 to $9 \mathrm{mo}$ ) and a resting period of ca. $7.2 \mathrm{mo}$ (range 4 to $7.2 \mathrm{mo}$ ).

\section{Variations in the pregnancy rate with age}

Reproductive senescence is a decline in age-specific fecundity with age (Promislow 1991), and for most cetacean species, reproductive senescence is rare and, when observed, often attributed to some pathological change (Hohn et al. 2007). However, reproductive success has been shown to vary throughout the life of a female odontocete. Initially, reproductive success is relatively low, peaks several years after attaining sexual maturity and then declines in later life (Chivers 2002). This has been noted in bottlenose dolphins Tursiops truncatus in Sarasota Bay, Florida (USA), where high mortality rates have been observed for first-born calves, with only ca. $50 \%$ surviving during their first year, whereas more than $70 \%$ of calves born to multiparous mothers survive (Wells 2000, Wells et al. 2005). The increase in reproductive success for multiparous mothers was attributed to a decline in the females' polychlorinated biphenyl (PCB) loads and/or an improvement in their physiological capabilities and behavioural experience in successfully rearing offspring (Wells et al. 2005). Following this, older females were reported to have extended breeding cycles, also noted in striped dolphins, as a result of longer calving intervals caused by an extended lactation period 

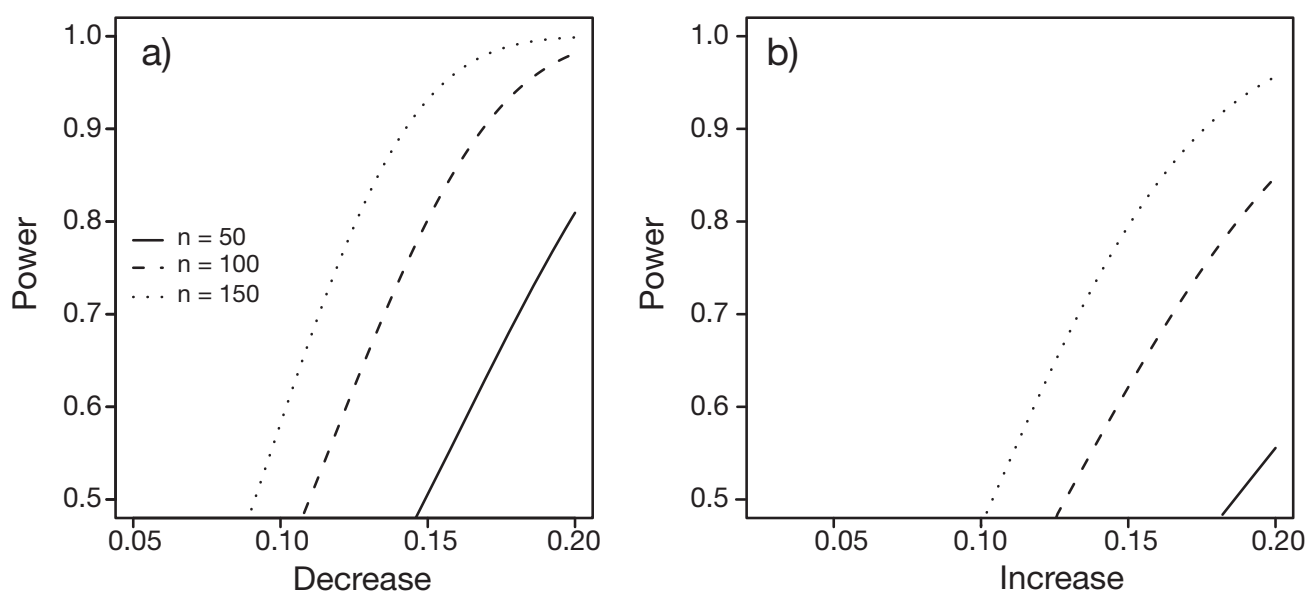

Fig. 8. Delphinus delphis. Power to detect absolute (a) decreases and (b) increases in pregnancy rate with 2 samples each of size $\mathrm{n}(2$-tailed test; $\alpha=0.05)$. The pregnancy rate during the first time period was assumed to be 0.25

(Miyazaki 1984, Wells 1993, Mann et al. 2000, Chivers 2002).

Reproductive success cannot be determined using postmortem data, but variations in the pregnancy rate and length of calving interval with age can be investigated. In the ETP, Danil \& Chivers (2007) observed a strong decline in the pregnancy rate with age and an increase in the length of lactation. This was attributed to either younger females weaning their calves earlier, or younger females being less successful at rearing their calves and becoming pregnant more often. Data from the ENA showed the proportion of pregnant females increased after 10 yr of age, but declined again in older age classes due to an extended breeding cycle.

Evidence of post-reproductive females, with senescent ovaries, have been observed in other odontocetes such as the short-fin pilot whale Globicephala macrorhynchus (Marsh \& Kasuya 1984) and Stenella spp. (Perrin et al. 1976, 1977). Danil \& Chivers (2007) found no clear evidence of post-reproductive females in the ETP population. Data on Delphinus delphis in the North Atlantic suggest that females are capable of reproducing until a late stage in life. Maximum age reported in the current study was $29 \mathrm{yr}$, although

Table 7. Delphinus delphis. Published data on mating/calving period, annual pregnancy rate (APR), calving interval (Cal), average age (ASM) and average body length (LSM). NA: not analysed

\begin{tabular}{|c|c|c|c|c|c|c|c|c|c|}
\hline Area & Climate & $\begin{array}{l}\text { Sample } \\
\text { Period }\end{array}$ & $\begin{array}{l}\text { Mating/ } \\
\text { calving } \\
\text { period }\end{array}$ & $\begin{array}{c}\text { APR } \\
\text { (presence of } \\
\text { foetus only) \% }\end{array}$ & $\begin{array}{c}\text { APR } \\
\text { (mature } \\
\text { sample, n) }\end{array}$ & $\begin{array}{c}\text { Cal } \\
(\mathrm{yr}) \\
(1 / \mathrm{APR})\end{array}$ & $\begin{array}{l}\text { ASM } \\
\text { (n) }\end{array}$ & $\begin{array}{l}\mathrm{LSM} \\
\text { (n) }\end{array}$ & Source \\
\hline $\begin{array}{l}\text { Eastern } \\
\text { North } \\
\text { Atlantic }\end{array}$ & Temperate & 1990-2006 & $\begin{array}{l}\text { May to } \\
\text { September }\end{array}$ & 26 & 248 & 3.79 & $\begin{array}{l}8.22^{\mathrm{d}} \\
(379)\end{array}$ & $\begin{array}{c}188.8^{\mathrm{a}} \\
(597)\end{array}$ & $\begin{array}{l}\text { This } \\
\text { study }\end{array}$ \\
\hline UK & Temperate & 1990-2005 & $\begin{array}{l}\text { May to } \\
\text { September }\end{array}$ & 33 & 46 & 3.05 & NA & $\begin{array}{c}191.61^{\mathrm{a}} \\
(80)\end{array}$ & $\begin{array}{l}\text { Control } \\
\text { group - } \\
\text { This study }\end{array}$ \\
\hline $\begin{array}{l}\text { Western } \\
\text { North } \\
\text { Atlantic }\end{array}$ & Temperate & 1989-1998 & $\begin{array}{l}\text { July to } \\
\text { August }\end{array}$ & 28 & 39 & 3.57 & $\begin{array}{l}8.33 \\
(64)\end{array}$ & NA & $\begin{array}{l}\text { Westgate \& } \\
\text { Read (2007) }\end{array}$ \\
\hline $\begin{array}{l}\text { Eastern } \\
\text { Tropical } \\
\text { Pacific }\end{array}$ & Tropical & 1979-1993 & $\begin{array}{l}\text { Calve all } \\
\text { year round }\end{array}$ & 47 & 333 & 2.14 & $\begin{array}{c}7.9^{\mathrm{d}} \\
(405)\end{array}$ & $\begin{array}{l}187^{a} \\
(700)\end{array}$ & $\begin{array}{c}\text { Danil \& } \\
\text { Chivers (2007) }\end{array}$ \\
\hline North Pacific & Temperate & 1990-1991 & $\begin{array}{l}\text { May to } \\
\text { June }\end{array}$ & NA & NA & NA & $8^{\mathrm{b}}$ & $172.8^{\mathrm{a}}$ & $\begin{array}{c}\text { Ferrero \& } \\
\text { Walker (1995) }\end{array}$ \\
\hline South Africa & Temperate & 1969-1988 & Summer & $40.2^{\mathrm{c}}$ & 93 & $2.5^{\mathrm{c}}$ & $\sim 8-9^{b}$ & ${ }^{N A}$ & $\begin{array}{l}\text { Mendolia (1989) } \\
\text { elphinus capensis }\end{array}$ \\
\hline
\end{tabular}


reproductive status was not assessed for this female, and the 2 oldest pregnant females were 25 and 26 yr of age. Another female aged 25 yr was lactating and was found entangled in a driftnet with her neonate calf. These data are consistent with the WNA population, in which the oldest female in the sample, estimated to be more than $30 \mathrm{yr}$ of age, was pregnant (Westgate \& Read 2007).

\section{Potential reproductive output}

The biological data from the ETP, including a calving interval of ca. $2.14 \mathrm{yr}$ (1/APR), a mean age at first birth of $10 \mathrm{yr}$ (Danil 2004) and a maximum age of $25 \mathrm{yr}$ (Danil \& Chivers 2007), suggests a reproductive period of ca. $15 \mathrm{yr}$ and a life time reproductive output of ca. 7 calves. In contrast, in the ENA, assuming we have obtained a representative sample from the population, a reproductive period of ca. $19 \mathrm{yr}$ and a potential lifetime reproductive output of approximately 4 to 5 calves is proposed, based on an average calving interval of ca. 4 yr, using Danil's (2004) estimate for age at first birth of $10 \mathrm{yr}$, and a maximum age of $29 \mathrm{yr}$ (although the majority of individuals were $\leq 26$ yr of age, see Fig. 2b).

\section{Evidence of density-dependent compensatory responses}

Fowler (1987) reported that the 3 parameters most often observed to change with density in marine mammals were ASM, birth rate and juvenile survival. Due to the nature of mortality data, we were unable to assess juvenile survival and birth rate directly, although temporal variations in APR, Cal, ASM, LSM, proportion of mature females in the sample, proportion of simultaneous pregnant and lactating females, and nutritional status were assessed. Observed changes in the above-mentioned biological parameters are expected if variations occur in the relative availability of food resources, as a result of changes in the environment and/or population density.

Within the 16 yr sampling period reported here, significance testing failed to detect differences that could be construed as evidence of the population exhibiting density-dependent responses; specifically, there was (1) a lack of significant temporal variation in the proportion of pregnant females, (2) no significant change in the ASM, (3) no significant variation in the proportion of mature females simultaneously pregnant and lactating and (4) no significant variation in the nutritional condition of females. Despite the fact that the difference in the ASM between decades (0.85 yr) was not significant, the low sample size for the indeterminate age classes, especially in the 1990s ( $\mathrm{n}=14$ individuals), resulted in low statistical power to detect a real difference. A significant increase in the number of mature females was reported in the sample between the 1990 s (45\%) and the 2000s (54\%), although it cannot be ruled out that this may be due to sampling biases. Whether the $16 \mathrm{yr}$ sampling period was too short to detect evidence of density-dependent compensatory responses in a long-lived mammal species should also be taken into account when interpreting the results. Kasuya (1985) reported changes in reproductive parameters for a striped dolphin Stenella coeruleoalba population heavily exploited by Japan's drive fishery in the western North Pacific, with a significant decline in the ASM from 9.7 to $7.4 \mathrm{yr}$ between cohorts sampled in 1956-58 and 1968-70, indications of a decline in the calving interval from $4.0 \mathrm{yr}$ in 1955 to $2.76 \mathrm{yr}$ in 1977, an increase in the proportion of females pregnant and lactating, and a decrease in the age of the youngest sexually mature female (Chivers \& Myrick 1993, Hohn et al. 2007).

In contrast, only small changes in reproductive parameters, including ASM and pregnancy rate, were observed when comparing heavily exploited populations against less exploited populations of both spinner Stenella longirostris and spotted dolphins S. attenuata. Following the years of peak mortality in fishing nets in the ETP, only an increase in the proportion of females simultaneously pregnant and lactating was detected in the northern-offshore spotted dolphin population, based on data collected between 1974 and 1988 (Chivers \& Myrick 1993). This may in part be due to high exploitation in the 1960s, which resulted in population regulation mechanisms being already in effect before life history sampling began (Chivers \& DeMaster 1994). Variations in growth and reproductive parameters were observed between the eastern spinner (17 to $25 \%$ of original size) and the less exploited northern whitebelly spinner (57 to $72 \%$ of original size) populations, based on data collected between 1968 and 1978, although there was no clear basis for indicating that greater exploitation of the eastern spinner population resulted in a higher reproductive rate (Perrin \& Henderson 1984). It was not ruled out that the whitebelly spinner dolphin population was below its maximum productivity level, and therefore also exhibiting responses to exploitation.

As mentioned previously, the lack of seasonality in the ETP Delphinus delphis population has been attributed to the highly productive tropical waters of the Costa Rica Dome enabling a higher proportion of females to be simultaneously pregnant and lactating (Danil \& Chivers 2007). The higher pregnancy rate of $47 \%$ and lower ASM of $7.9 \mathrm{yr}$ in the ETP population 
compared to the ENA population $(26 \%, 8.22 \mathrm{yr})$ suggest that $D$. delphis inhabiting the ETP are inherently different due to the environment that they inhabit and, as a result, have a higher per capita reproductive output (Danil \& Chivers 2007). Interestingly, a larger variation between the 2 populations occurred in the pregnancy rate, and not the ASM. Limitations to how frequently a small delphinid can reproduce in a temperate environment relative to a warm-water, high-productivity environment may be an additional reason for the lower pregnancy rate in North Atlantic D. delphis. Data from D. capensis off South Africa confirm that common dolphins inhabiting temperate environments can have relatively short calving intervals (ca. 2 yr; Mendolia 1989), although it should be noted that sustained increase in calving rates are only possibly when resource levels are high and there are no limitations from energetic needs (Hohn et al. 2007). In fin whales Balaenoptera physalus, after heavy commercial exploitation and during years of high prey abundance, the normal $2 \mathrm{yr}$ breeding cycle was compressed to a 1 yr cycle. However, this did not continue indefinitely, as whales that calved in 2 consecutive years did not ovulate during the third year, possibly due to energetic constraints (Lockyer 1987, Hohn et al. 2007).

Some populations may be more vulnerable and less adaptable to change after being subjected to extremely high mortality rates. A threshold may apply, for example if populations are depleted below a certain level they may not recover at a rate consistent with estimated levels of depletion, even if a substantial decline in the bycatch mortality rate has occurred, i.e. depensatory ('Allee') effect at low population size (Gerrodette \& Forcada 2005). As mentioned earlier within the ENA, although incidental capture of Delphinus delphis in fishing gear has been reported in a large number of different net types/fisheries, it has not been suggested that the annual incidental mortality rate has been, or is, on a scale similar to the peak historical rates observed in the ETP. Approximately 6 million dolphins were killed by the yellowfin tuna fishery in the ETP since it was established 4 decades ago. The number of animals reached a peak towards the end of the 1960s, with almost 700000 dolphins killed in 1 yr. However, by the end of the $1970 \mathrm{~s}$, the kill had declined to approximately 20000 dolphins $\mathrm{yr}^{-1}$ (Gerrodette 2002). In 1986, the total dolphin mortality had increased to 133000 individuals, but due to various political and economic pressures, dolphin mortality decreased again (Gerrodette 2002). Northeastern offshore spotted dolphins Stenella attenuata and eastern spinner dolphins $S$. longirostris orientalis, followed by short-beaked common dolphins, were the main species caught in yellowfin tuna fishing nets. On the whole, the ETP D. delphis population has been relatively stable since the 1980s (Anganuzzi \& Buckland 1994), and therefore evidence of density-dependent changes in life history parameters were not expected in the study by Danil \& Chivers (2007). For the most part, samples utilised in the ETP study were obtained predominately in the 1970s and 1980s (1975 to 1993), during which time a mean annual mortality of 4551 (range 191 to $12711)$ D. delphis was determined for this region (1973 to 1993; Bayliff 2002), which is higher than the annual potential biological removal estimate of 3109 individuals calculated for the period 1996 to 2000 (Gerrodette 1996).

The $26 \%$ pregnancy rate calculated for the ENA population may well in fact be the natural rate for a common dolphin population inhabiting a cool temperate region, although we cannot exclude the possibility that environmental and other anthropogenic activities, such as chemical and physical pollutants, may be contributing factors to the low reproductive output. The EC-BIOCET project investigated bioaccumulation of persistent organic pollutants in female Delphinus delphis and showed that the threshold for effects on reproduction, identified by Kannan et al. (2000) as a $\Sigma$ PCB level of $17 \mu \mathrm{g} \mathrm{g}^{-1}$ lipid in liver in aquatic mammals, was frequently exceeded $(40 \%)$ in $D$. delphis (Pierce et al. 2008). Results also showed that the incidence of pregnancy was significantly negatively related to the concentrations of PCBs and brominated diphenyl ether formulations in blubber; thus, pregnant females had lower persistent organic pollutant (POP) concentrations than other mature females. However, Pierce et al. (2008) stated that these relationships do not conclusively demonstrate that high POP concentrations inhibit pregnancy, as infertility due to other causes may allow high levels of POPs to bioaccumulate.

Unlike other cetaceans in the ENA, such as the harbour porpoise Phocoena phocoena (Jepson et al. 2005), mortality due to infectious disease is rare (Jepson 2005) and there is a lack of evidence of large-scale epizootics, as reported for striped dolphins in the Mediterranean Sea (Aguilar 2000), bottlenose dolphins in the WNA (Duignan et al. 1996), and common dolphins Delphinus delphis ponticus in the Black Sea (Birkun et al. 1999). Whether the actual carrying capacity for the D. delphis ENA population has declined due to a decrease in available prey species is unknown, although a lack of observed temporal variation in nutritional condition during the 16 yr time period implies that $\mathrm{K}$ has not declined. Stomach contents of D. delphis in the ENA revealed that they are opportunistic feeders and adapt to changes in prey availability. For example, off the Spanish coast, higher numbers of sardines were consumed in years of higher sardine 
abundance and lower recruitment of blue whiting, another main prey (Santos et al. 2004). Furthermore, during the middle of the last century, a northwards shift in the distribution of $D$. delphis occurred in the ENA, possibly in response to changes in prey availability and water temperature (Murphy et al. 2006, and references therein), which suggests an ability to adapt to changing environments. On the whole, the diet of $D$. delphis in the ENA is predominately composed of a few main species, which vary depending on the season and the region they are inhabiting (see Murphy et al. 2008, and references therein). A large number of other prey species are consumed, albeit in lower numbers.

\section{Assessing the current status of the ENA population}

Conservation management of a species should ideally be underpinned by knowledge of population status, e.g. distribution, abundance and the effects of anthropogenic activities on the population. For Delphinus delphis in the ENA, no population-level information is available on trends in abundance, (incidental) mortality rates or even the actual distributional range of the population. Therefore, it was necessary in the current study to examine and present basic life history/vital rate data, and investigate whether biological information is, in itself, useful for managing this population.

To assess whether the overall APR of $26 \%$ determined in this study ( $\mathrm{n}=248$ mature females) is a good indication for the actual pregnancy rate in the population, the APR was estimated for a control group of individuals diagnosed during detailed necropsies as bycaught and found to be free from any infectious or non-infectious disease (or loss of nutritional status) that may affect reproduction. Using the control group, a higher APR of $33 \%$ ( $\mathrm{n}=46$ mature females) was obtained, but this rate was not significantly different from the whole dataset. However, power analysis suggested that the sample size of the control group might have been too small to detect a real difference in the proportion of pregnant females. Although the APR of the control group was $7 \%$ higher than the value obtained using the whole dataset, the real APR will be lower than this, since any population will include both healthy animals and individuals that are unable to reproduce due to ill health or other reasons. The vast majority of stranded Delphinus delphis in western European waters are individuals that died as a result of incidental capture in fishing nets (Murphy 2004, Jepson 2005), and older individuals (>20 yr) were not notably over-represented in the stranding and bycatch data. Therefore, for the $D$. delphis population in the ENA, using data from both bycaught and stranded ani- mals is deemed appropriate for estimating population life history parameters.

For future assessment of potential changes in population dynamics, large sample sizes (100 to 150 mature females) are required to obtain sufficient statistical power to detect temporal variations in the proportion of pregnant females. It has been reported in other studies, e.g. Hohn (1989) and Chivers \& Myrick (1993), that adequate age and reproductive data from females in the indeterminate age classes is also vital for estimating the ASM. In reality, obtaining such a large sample size of sexually immature and mature females is difficult and requires that European stranding and observer bycatch programmes continue sampling all available and suitable carcasses. Power analysis also suggested that extremely large variations in the pregnancy rate would have to occur in order to detect a significant increase or decrease, i.e. based on the sample sizes in the current study, only absolute changes in pregnancy rate of 13 to $20 \%$ would have been detectable with decent statistical power. It should be noted that we have focused here on the detection of significant changes in the pregnancy rate, and changes may become biologically significant before they can be detected statistically.

The overall low pregnancy rate and low lifetime reproductive output in the current study could suggest that (1) the population growth rate is declining, (2) the population is approaching carrying capacity and/or (3) carrying capacity is declining. Further, the low APR reported throughout the sampling period could also suggest that the level of anthropogenic mortality during this period did not cause a substantial population level decline. It cannot be ruled out that the low APR may also indicate a prey base declining at approximately the same rate as the dolphin population declines. As mentioned previously, analysing data obtained from necropsies was the only means possible for assessing reproductive parameters for this oceanic delphinid species. It enabled us to determine a wide variety of life-history traits, information that is vital for understanding the dynamics of this population and for production of management plans. The current study highlights that this approach alone does not facilitate an assessment of the current state of the Delphinus delphis population in the ENA. Previous studies on Stenella species further emphasise this point (see Perrin \& Henderson 1984, Chivers \& DeMaster 1994), as a lack of knowledge on population dynamics (such as the population level relative to carrying capacity or its original size) and the timing of sampling in relation to exploitation (it is preferable to sample life history parameters when the population is actually responding to a reduction in population level) all confound correct interpretation of life history data. In conclusion, popu- 
lation abundance estimates, trends in abundance and knowledge of factors that affect the dynamics of the population, for example annual mortality rates in fisheries, temporal variations in prey abundance and effects of contaminants on reproductive activity, are required not only to set management objectives for this population, but also to give context to cross-sectional life history information.

Acknowledgements. This research was undertaken as part of the EC-funded NECESSITY Project (NEphrops and CEtacean Species Selection Information and TechnologY, contract 501605), and under contract to the UK Department of the Environment, Food and Rural Affairs (DEFRA, contract MF0736). Data used in the current study were also obtained as part of the EC-funded BIOCET project (BIOaccumulation of persistent organic pollutants in small CETaceans in European waters: transport pathways and impact on reproduction, EVK3-2000-00027). Thanks to J. McVee for sectioning the UK Delphinus delphis teeth samples. The UK Cetacean Strandings Investigation Programme (CSIP) funded by DEFRA, as part of its commitment to the Agreement on the Conservation of Small Cetaceans of the Baltic and North Seas, supplied data and tissue samples. In Ireland, members of the Irish Whale and Dolphin Group assisted with data collection. Members of CEMMA attended strandings in Galicia. Data from Portugal were provided by the Portuguese Marine Mammal Stranding Network, coordinated by the Nature Conservation Institute. Sampling in France was carried out by the Réseau National Echouages, and coordinated by the Centre de Recherche sur les Mammifères Marins (CRMM) of La Rochelle. We thank W. Blanchard for helpful comments on some of the statistical analyses.

\section{LITERATURE CITED}

Aguilar A (2000) Population biology, conservation threats and status of Mediterranean striped dolphins. J Cetacean Res Manag 2:17-26

Amaral AR, Sequeira M, Martíinez-Cedeira J, Coelho MM (2007) New insights on population genetic structure of Delphinus delphis from the northeast Atlantic and phylogenetic relationships within the genus inferred from two mitochondrial markers. Mar Biol 151:1967-1976

Anganuzzi AA, Buckland S (1994) Relative abundance of dolphins associated with tuna in the eastern Pacific Ocean: analysis of 1992 data. Rep Int Whaling Comm 44:361-366

Au DWK, Perryman WL (1985) Dolphin habitats in the eastern tropical Pacific. Fish Bull (Wash DC) 83:623-643

Barlow J (1984) Reproductive seasonality in pelagic dolphins (Stenella spp.): implications for measuring rates. In: Perrin WF, Brownell RL Jr, DeMaster DP (eds) Reproduction of whales, dolphins and porpoises, Spec Issue 6. Int Whaling Comm, Cambridge, p 191-198

Bayliff WH (2002) Annual report of the Inter-American Tropical Tuna Commission, 2000. Inter-American Tropical Tuna Commission, La Jolla, CA

Best PB (2007) Long-beaked common dolphin Delphinus capensis. In: Best PB (ed) Whales and dolphins of the southern African subregion. Cambridge University Press, Cambridge, p 218-222

Birkun A Jr, Kuiken T, Krivokhizhin S, Haines DM and others (1999) Epizootic of morbilliviral disease in common dol- phins (Delphinus delphis ponticus) from the Black Sea. Vet Rec 144:85-92

Börjesson P, Read AJ (2003) Variation in timing of conception between populations of the harbor porpoise. J Mammal 84:948-955

Burnham KP, Anderson DR (2002) Model selection and multimodel inference: a practical information-theoretic approach, 2nd edn. Springer, New York

Calder WA (1982) The pace of growth: an allometric approach to comparative embryonic and post-embryonic growth. J Zool 198:215-225

Chivers SJ (2002) Cetacean life history. In: Perrin WF, Würsig B, Thewissen JGM (eds) Encyclopaedia of marine mammals. Academic Press, San Diego, CA, p 221-225

Chivers SJ, DeMaster DP (1994) Evaluation of biological indices for three Eastern Pacific dolphin species. J Wildl Manag 58:470-478

Chivers SJ, Myrick AC (1993) Comparison of age at sexual maturity and other reproductive parameters for two stocks of spotted dolphins, Stenella attenuata. Fish Bull (Wash DC) 91:611-618

Collet A (1981) Biologie du dauphin commun Delphinus delphis L. en Atlantique Nord-Est. PhD thesis, Université de Poitiers

Cooke JG (1984) The estimation of mean ages at sexual maturity from age data. Rep Int Whaling Comm SC/36/022:1-8

Danil K (2004) Growth and reproduction of female shortbeaked common dolphins, Delphinus delphis, in the eastern tropical Pacific. MSc thesis, University of California, San Diego

> Danil K, Chivers SJ (2007) Growth and reproduction of female short-beaked common dolphins, Delphinus delphis, in the eastern tropical Pacific. Can J Zool 85:108-121

DeMaster DP (1978) Calculation of the average age at sexual maturity in marine mammals. J Fish Res Board Can 36: 912-915

DeMaster DP (1984) Review of techniques to estimate the average age at attainment of sexual maturity in marine mammals. In: Perrin WF, Brownell RL Jr, DeMaster DP (eds) Reproduction in whales, dolphins and porpoises, Spec Issue 6. Int Whaling Comm, Cambridge, p $175-180$

> Doksaeter L, Olsen E, Nottestad L, Ferno A (2008) Distribution and feeding ecology of dolphins along the MidAtlantic Ridge between Iceland and the Azores. Deep Sea Res II 55:243-253

Duignan PJ, House C, Odell DK, Wells RS and others (1996) Morbillivirus infection in bottlenose dolphins: evidence for recurrent epizootics in the western Atlantic and Gulf of Mexico. Mar Mamm Sci 12:499-515

Eberhardt LL, Siniff DB (1977) Population dynamics and marine mammal management policies. J Fish Res Board Can 34:183-190

Evans WE (1975) Distribution, differentiation of populations, and other aspects of the natural history of Delphinus delphis Linnaeus in the northeastern Pacific. PhD thesis, University of California, Los Angeles

Ferrero RC, Walker WA (1995) Growth and reproduction of the common dolphin, Delphinus delphis Linnaeus, in the offshore waters of the North Pacific Ocean. Fish Bull (Wash DC) 93:483-494

Fitzhugh HAJ (1976) Analysis of growth curves and strategies for altering their shape. J Anim Sci 42:1036-1051

> Fowler CW (1981) Density dependence as related to life history strategy. Ecology 62:602-610

Fowler CW (1984) Density dependence in cetacean populations. In: Perrin WF, Brownell RL Jr, DeMaster DP (eds) 
Reproduction in whales, dolphins and porpoises, Spec Issue 6. Int Whaling Comm, Cambridge, p 373-379

Fowler CW (1987) A review of density dependence in populations of large mammals. In: Genoways HH (ed) Current mammalogy, Vol 1. Plenum Publishers Corporation, New York, p 01-441

Fox J (2002) Nonlinear regression and nonlinear least squares. Appendix to 'An R and S-PLUS companion to applied regression'. http://cran.r-project.org/doc/contrib/Fox-Companion/appendix-nonlinear-regression.pdf

Gerrodette T (1996) A comparison of mortality limits for eastern tropical Pacific dolphins under the Declaration of Panama and under potential biological removal (PBR) management. Admin Rep LJ-96-18, Southwest Fisheries Science Center, La Jolla, CA (available at: http://swfsc. noaa.gov)

Gerrodette $\mathrm{T}$ (2002) Tuna-dolphin issue. In: Perrin WF, Würsig B, Thewissen JGM (eds) Encyclopedia of marine mammals. Academic Press, San Diego, CA, p 1269-1273

Gerrodette T, Forcada J (2005) Non-recovery of two spotted and spinner dolphin populations in the eastern tropical Pacific Ocean. Mar Ecol Prog Ser 291:1-21

Goujon M, Antoine L, Collet A, Fifas S (1993) Approche de l'mpact de la ecologique de la pecherie thoniere au filet maillant derivant en Atlantique nord-est. Rapport interne de la Direction des Resources Vivantes de I'IFREMER. Ifremer. Centre de Brest, BP 70:29280 Plouzane

Gurevich VS, Stewart LH, Cornell LH (1980) The use of tetracycline in age determination of common dolphins, Delphinus delphis. In: Perrin WF, Myrick AC (eds) Age determination of toothed whales and sirenians, Spec Issue 3. Int Whaling Comm, Cambridge, p 165-169

Heyning JE, Perrin WF (1994) Evidence of two species of common dolphins (genus Delphinus) from the eastern North Pacific. Contributions in Science (Los Angeles) 442:1-35

Hohn AA (1989) Variation in life-history traits: the influence of introduced variation. $\mathrm{PhD}$ thesis, University of California, Los Angeles

Hohn AA, Ewing RY, Zaias J (2007) Reproduction in relation to conservation and commercial exploitation. In: Miller DL (ed) Reproductive biology and phylogeny of Cetacea, Vol 7 of series: Reproductive biology and phylogeny. Science Publishers, Enfield, NH, p 371-389

Huggett A, Widdas WF (1951) The relationship between mammalian foetal weight and conception age. J Physiol 114:306-317

Innes S, Stewart REA, Lavigne DM (1981) Growth in Northwest Atlantic harp seals Phoca groenlandica. J Zool 194: $11-24$

Jefferson TA, Van Waerebeek K (2002) The taxonomic status of the nominal dolphin species, Delphinus tropicalis van Bree, 1971. Mar Mamm Sci 18:787-818

Jepson PD (2005). Trends in cetacean strandings around the UK coastline and cetacean and marine turtle post-mortem investigations, 2000 to 2004 inclusive (Contract CRO 238). Cetacean Strandings Investigation Programme (CSIP) report to DEFRA for the period 1 January 2000 - 31 December 2004, p 1-79

Jepson PD, Bennett PM, Deaville R, Allchin CR, Baker JR, Law RJ (2005) Relationships between polychlorinated biphenyls and health status in harbour porpoises (Phocoena phocoena) stranded in the United Kingdom. Environ Toxicol Chem 24:238-248

Kannan K, Blankenship AL, Jones PD, Giesy JP (2000) Toxicity reference values for the toxic effects of polychlorinated biphenyls to aquatic mammals. Hum Ecol Risk Assess 6: 181-201
Kasuya T (1985) Effect of exploitation on reproductive parameters of the spotted and striped dolphins off the Pacific coast of Japan. Sci Rep Whale Res Inst 36:107-138

Kuiken T, Garcia Hartmann M (eds) (1991) Proceedings of the first European Cetacean Society workshop on 'Cetacean pathology: dissection techniques and tissue sampling'. ECS Newslett 17:1-39

Kuiken T, Simpson VR, Allchin CR, Bennet PM and others (1994) Mass mortality of common dolphins (Delphinus delphis) in south west England due to incidental capture in fishing gear. Vet Rec 134:81-89

Law RJ (1994) Collaborative UK marine mammal project: summary of data produced 1988-1992. Fish Res Tech Rep 97. Directorate of Fisheries Research, Ministry of Agriculture, Fisheries and Food, Lowestoft

Lockyer CH (1987) Evaluation of the role of fat reserves in relation to the ecology of North Atlantic fin and sei whales. In: Huntley AC, Costa DP, Worthy GAJ, Castellini MA (eds) Approaches to marine mammal energetics. Society for Marine Mammalogy, Lawrence, KS, p 183-203

Lockyer CH (1990) The importance of biological parameters in population assessments with special reference to fin whales from the N.E. Atlantic. North Atl Stud 2:22-31

Lockyer CH (1995) A review of factors involved in zonation in odontocete teeth, and an investigation of the likely impact of environmental factors and major life events on harbour porpoise teeth structure. In: Bjorge A, Donovan GP (eds) Biology of the phocoenids, Spec Issue 16. Int Whaling Comm, Cambridge, p 511-529

- López A, Santos MB, Pierce GJ, González AF, Valeiras X, Guerra A (2002) Trends in strandings and by-catch of marine mammals in north-west Spain during the 1990s. J Mar Biol Assoc UK 82:513-521

Mann J, Connor RC, Barre LM, Heithaus MR (2000) Female reproductive success in bottlenose dolphins (Tursiops sp.): life history, habitat, provisioning, and group-size effects. Behav Ecol 11:210-219

Marsh H, Kasuya T (1984) Changes in the ovaries of shortfinned pilot whales, Globicephala macrorhynchus, off the Pacific coast of Japan. In: Perrin WF, Brownell RL Jr, DeMaster DP (eds) Reproduction in whales, dolphins and porpoises, Spec Issue 6. Int Whaling Comm, Cambridge, p 311-336

Mendolia C (1989) Reproductive biology of common dolphins (Delphinus delphis Linnaeus) off the south east coast of southern Africa. MSc thesis, University of Port Elizabeth

Mirimin L, Viricel A, Amaral AR, Murphy S, Ridoux V, Rogan E (2007) Stock structure in the common dolphin Delphinus delphis in the Northeast Atlantic: analysis of genetic material. EC NECESSITY Contract 501605 Periodic Activity Report No 2 - Annex 8.1.a

Miyazaki N (1984) Further analyses of reproduction in the striped dolphin, Stenella coeruleoalba, off the Pacific coast of Japan. In: Perrin WF, Brownell RL Jr, DeMaster DP (eds) Reproduction of whales, dolphins and porpoises, Spec Issue 6. Int Whaling Comm, Cambridge, p 343-353

Murphy S (2004) The biology and ecology of the common dolphin Delphinus delphis in the North-east Atlantic. PhD thesis, University College Cork

> Murphy S, Rogan E (2006) External morphology of the shortbeaked common dolphin, Delphinus delphis: growth, allometric relationships and sexual dimorphism. Acta Zool 87: 315-329

Murphy S, Collet A, Rogan E (2005) Mating strategy in the male common dolphin Delphinus delphis: what gonadal analysis tells us. J Mammal 86:1247-1258 
Murphy S, Herman JS, Pierce GJ, Rogan E, Kitchener AC (2006) Taxonomic status and geographical cranial variation of common dolphins (Delphinus) in the eastern North Atlantic. Mar Mamm Sci 22:573-599

Murphy S, Evans PGH, Collet A (2008) Common dolphin Delphinus delphis. In: Harris S, Yalden DW (eds) Mammals of the British Isles handbook 4th edn. The Mammal Society, Southampton, p 719-724

Natoli A, Canadas A, Peddemors VM, Aguilar A, Vaquero C, Fernandez-Piqueras P, Hoelzel AR (2006) Phylogeography and alpha taxonomy of the common dolphin (Delphinus sp.). J Evol Biol 19:943-954

Natoli A, Cañadas A, Vaquero C, Politi E, Fernandez-Navarro P, Hoelzel AR (2008) Conservation genetics of the shortbeaked common dolphin (Delphinus delphis) in the Mediterranean Sea and in the eastern North Atlantic Ocean. Conserv Genet 9:1479-1487

Northridge S, Morizur Y, Souami Y, Van Canneyt O (2006) Final PETRACET report to the European Commission. Project EC/FISH/2003/09, 1735R07D. Lymington

Northridge S, Kingston A, Thomas L, Mackay A (2007) Second annual report on the UK Cetacean bycatch monitoring scheme. Contract report to DEFRA on the work conducted 2005-2006. Sea Mammal Research Unit, St. Andrews

Perrin WF, Donovan GP (1984) Report of the workshop. In: Perrin WF, Brownell RL Jr, DeMaster DP (eds) Reproduction of whales, dolphins and porpoises, Spec Issue 6. Int Whaling Comm, Cambridge, p 1-24

Perrin WF, Henderson JR (1984) Growth and reproductive rates in two populations of spinner dolphins, Stenella longirostris, with different histories of exploitation. In: Perrin WF, Brownell RL Jr, DeMaster DP (eds) Reproduction of whales, dolphins and porpoises, Spec Issue 6. Int Whaling Comm, Cambridge, p 417-427

Perrin WF, Coe JM, Zweifel JR (1976) Growth and reproduction of the spotted porpoise, Stenella attenuata, in the offshore eastern tropical Pacific. Fish Bull (Wash DC) 74: 229-269

Perrin WF, Holts DB, Miller RG (1977) Growth and reproduction in the eastern spinner, a geographical form of Stenella longirostris in the eastern tropical Pacific. Fish Bull (Wash DC) 75:725-750

Perrin WF, Chivers SJ, Archer FI II. (2003) Fetal mortality in dolphins exploited by the tuna fishery. In: Abstracts of the 15th Biennial Conference on the Biology of Marine Mammals, Greensboro, NC

Perryman WL, Lynn MS (1993) Identification of geographic forms of common dolphin (Delphinus delphis) from aerial photogrammetry. Mar Mamm Sci 9:119-137

Pierce GJ, Santos MB, Murphy S, Learmonth JA and others (2008) Bioaccumulation of persistent organic pollutants in female common dolphins (Delphinus delphis) and harbour porpoises (Phocoena phocoena) from western European seas: geographical trends, causal factors and effects on reproduction and mortality. Environ Pollut 153: 401-415

> Promislow DEL (1991) Senescence in natural populations of mammals: a comparative study. Evolution 45:1869-1887

R Development Core Team 2007. R: a language and environment for statistical computing. R Foundation for Statistical Computing, Vienna. Available at: www.R-project.org

Richards FJ (1959) A flexible growth function for empirical use. J Exp Bot 10:290-301

> Rogan E, Mackey M (2007) Megafauna bycatch in drift nets

Editorial responsibility: Hans Heinrich Janssen, Oldendorf/Luhe, Germany for albacore tuna (Thunnus alalunga) in the NE Atlantic. Fish Res 86:6-14

Rogan E, Murphy S, Learmonth JA, González A, Dabin W (2004) Age determination in small cetaceans from the NE Atlantic. Appendix 4. In: Pierce GJ, Santos MB, Learmonth JA, Smeenk, C and others (eds) Bioaccumulation of persistent organic pollutants in small cetaceans in European waters: transport pathways and impact on reproduction. Final Report to the European Commission's Directorate General for Research on Project EVK3-200000027, Aberdeen

Santos MB, Pierce GJ, López A, Martinez MT and others (2004) Variability in the diet of common dolphins (Delphinus delphis) in Galician waters 1991-2003 and relationships with prey abundance. ICES CM 2004/ Q:09

Silva MA, Sequeira M (2003) Patterns in the mortality of common dolphins (Delphinus delphis) on the Portuguese coast, using stranding records 1975-1998. Aquat Mamm 29:88-98

> Stolen MK, Barlow J (2003) A model life table for bottlenose dolphins (Tursiops truncatus) from the Indian river lagoon system, Florida, U.S.A. Mar Mamm Sci 19:630-649

> Taylor BL, DeMaster DP (1993) Implications of non-linear density dependence. Mar Mamm Sci 9:360-371

Tregenza NJC, Berrow SD, Hammond PS, Leaper R (1997) Common dolphin Delphinus delphis L., bycatch in bottom set gillnets in the Celtic Sea. Rep Int Whaling Comm 47: 835-839

- Urian KW, Duffield DA, Read AJ, Wells RS, Shell ED (1996) Seasonality of reproduction in bottlenose dolphins, Tursiops truncatus. J Mammal 77:394-403

Venables WN, Ripley BD (2002) Modern applied statistics with S. 4th edn. Springer, New York

Viricel A (2006) Spatial and social structure of the common dolphin Delphinus delphis in the Northeast Atlantic inferred from genetic data. MSc thesis, College of Charleston, University of South Carolina, SC

Wade P (2002) Population dynamics. In: Perrin WF, Würsig B, Thewissen JGM (eds) Encyclopaedia of marine mammals. Academic Press, London, p 974-979

Wells RS (1993) Parental investment patterns of wild bottlenose dolphins. In: Hecker NF (ed) Proc 18th Int Mar Anim Trainers Assoc Conf, Chicago, IL, p 58-64

Wells RS (2000) Reproduction in wild bottlenose dolphins: overview of patterns observed during a long-term study. In: Duffield D, Robeck T (eds) Bottlenose dolphin reproduction workshop report, AZA Marine Mammal Taxon Advisory Group, Silver Spring, MD, p 57-74

Wells RS, Tornero V, Borrell A, Aguilar A and others (2005) Integrating life-history and reproductive success data to examine potential relationships with organochlorine compounds for bottlenose dolphins (Tursiops truncatus) in Sarasota Bay, Florida. Sci Total Environ 349:106-119

Westgate AJ (2005) Population structure and life history of short-beaked common dolphins (Delphinus delphis) in the North Atlantic. PhD thesis, Nicholas School of the environment and Earth Science, Duke University, Durham, North Carolina, NC

Westgate AJ (2007) Geographic variation in cranial morphology of short-beaked common dolphins (Delphinus delphis) from the North Atlantic. J Mammal 88:678-688

Westgate AJ, Read AJ (2007) The life history of short-beaked common dolphins (Delphinus delphis) in the western North Atlantic. Mar Biol 150:1011-1024

Submitted: April 4, 2008; Accepted: May 26, 2009

Proofs received from author(s): August 4, 2009 